\title{
National Rural Employment Guarantee Scheme, Poverty and Prices in Rural India ${ }^{1}$
}

\author{
Raghav Gaiha \\ Centre for Population and Development Studies, Harvard University, MA, USA \\ and Faculty of Management Studies, University of Delhi. India \\ Vani S. Kulkarni \\ Department of Sociology, Harvard University, MA, USA \\ Manoj K. Pandey \\ Institute of Economic Growth, Delhi, India \\ Katsushi S. Imai \\ Economics, School of Social Sciences, University of Manchester, UK \\ $7^{\text {th }}$ May 2009
}

\begin{abstract}
The objective of this analysis is mainly to construct an intuitive measure of the performance of the National Rural Employment Guarantee Scheme (NREGS) in India -a nation-wide poverty alleviation programme which was introduced in 2005. The focus is on excess demand at the district level. Some related issues addressed are (i) whether excess demand responds to poverty, and (ii) whether recent hikes in NREGS wages are inflationary. Our analysis confirms responsiveness of excess demand to poverty. Also, apprehensions expressed about the inflationary potential of recent hikes in NREGS wages have been confirmed. More importantly, higher NREGS wages are likely to undermine self-selection of the poor in it. So, in order to realise the poverty reducing potential of this scheme, a policy imperative is to ensure a speedier matching of demand and supply in districts that are highly poverty prone, as also to avoid the trade-offs between poverty reduction and inflation.
\end{abstract}

Key words: Employment Guarantee, NREGS, wages, demand, supply, poverty, prices, India

JEL codes: C21, I30, I38, J48, O12

\footnotetext{
${ }^{1}$ We are grateful to Raghbendra Jha and Shylashri Shankar for helpful advice. We are also grateful to Indranil Dutta for incisive comments on an earlier draft and from saving us from an error. Any deficiencies, however, are the sole responsibility of the authors.

${ }^{2}$ Corresponding Author: Dr Katsushi S. Imai, Economics, School of Social Sciences, University of Manchester, Arthur Lewis Building, Oxford Road, Manchester M13 9PL, UK; Telephone: +44-(0)161275-4827, Fax: +44-(0)161-275-4812 Email: Katsushi.Imai@manchester.ac.uk.
} 


\section{National Rural Employment Guarantee Scheme, Poverty and Prices in Rural India}

\section{Introduction}

There has been a spate of studies designed to assess the performance of the National Rural Employment Guarantee Scheme (NREGS hereafter) during two years of its existence. ${ }^{3}$ Various commentators have drawn attention to huge leakages and fudging of muster rolls, while others have been ecstatic over the number of jobs created, and number of beneficiaries from disadvantaged groups such as the Scheduled Tribes (ST), Scheduled Castes (SC) and women. So it is hardly surprising that many have debunked this nation-wide programme while others have given a strong endorsement on the grounds that it is beginning to transform the lives of the poor and making them better aware of their entitlements. In a broad sense, one view does not entirely negate the other, as impact assessment involves several different elements. From this perspective, we have constructed a few intuitive indicators and illustrated their implications for the success or failure of this intervention. The issue is an important one, as the recent decision to extend it to all 604 districts with an employment guarantee of 100 days per household is likely to be a huge fiscal burden (about Rs 53000 crore) — especially when the public finances of both the central and state governments are in disarray.

Our analysis is built around the following indicators: demand for and supply of NREGS jobs, excess demand (or the gap between them), and whether excess demand has widened in the last two years (i.e. 2007-08 and 2008-09), and the underlying factors. ${ }^{4}$ We also examine whether

\footnotetext{
${ }^{3}$ Several important contributions have appeared in Economic and Political Weekly and elsewhere (e.g., Dreze and Khera, 2009, Mehrotra, 2008, Ambastha et al. 2008, Gopal, 2009, Jha et al. 2008, Jha, Bhattacharya, Gaiha, Shankar, 2009, Jha, et al., 2009a, and Scandizzo et al. 2009).

${ }^{4}$ We have followed Indranil Dutta's suggestion that 'demand-supply gap' should be replaced by 'excess demand'. In applying this terminology, however, it is necessary to bear in mind that, while in a stable competitive equilibrium excess demand will lead to a higher price and a convergence to equilibrium, such a mechanism is unlikely to work as NREGS wages are also influenced by budgetary constraints and political cycles. So, if NREGS wages do not rise to clear the market because of these constraints there will be rationing of NREGS jobs. Arguably, this seems an appropriate characterisation of the scheme in question. A related issue is whether excess demand has any relevance as a performance indicator after the former drops to 0 . In principle, this is a valid comment except that it overlooks that the disequilibrium may persist for some time. We owe this clarification to Raghbendra Jha.
} 
excess demand is sensitive to headcount poverty ratio, and whether higher NREGS wages are likely to be inflationary, as highlighted in recent media reports. ${ }^{5}$

These indicators of supply and demand are an improvement on simplistic and arguably flawed estimates given on the NREGS website (http://nrega.nic.in/). For a sub-sample of 6 states, at the district level, the gap between supply and demand is 0 or almost 0 in most cases, suggesting a perfect matching. Given substantial evidence of fudging of muster rolls, and inaccurate estimation of demand (for lack of awareness, among other reasons), the estimates on the NREGS website cannot be taken at face value. So we measure these indicators with a modicum of economic theory (i.e. by linking them to "prices"). These estimates are then used to obtain more refined excess demand estimates. Briefly, the lower the excess demand, the more successful is NREGS. We then proceed to analyse whether excess demand responds to variation in the incidence of poverty. In other words, we ask whether more people demand this entitlement if there is more poverty in a district. Finally, we examine the likely impact of hikes in minimum NREGS wage rates on CPIAL (Consumer Price Index for Agricultural Labourers).

Much of the data are obtained from the NREGS website (http://nrega.nic.in/) and Reserve Bank of India website (http://www.rbi.org.in/). District level rural poverty estimates based on the $61^{\text {st }}$ round of the National Sample Survey (NSSO) are taken from Chaudhuri and Gupta (2009). The period covered is 2007-08 and 2008-09. For reasons of time and budget constraints, the analysis is based on data for six major states viz., Andhra Pradesh, Bihar, Madhya Pradesh, Rajasthan, Tamil Nadu, and Uttar Pradesh. The rest of the paper is structured as follows. Section II sketches the rationale of NREGS. The estimation strategy for excess demand for NREGS is outlined in Section III, and the corresponding regression results are discussed in Section IV. Section V turns to the sensitiveness of excess demand to variation in inter-district poverty. Section VI econometrically investigates whether hikes in NREGS wages are likely to be inflationary. The final section offers concluding observations with some policy implications.

\footnotetext{
${ }^{5}$ A recent report in The Economic Times states that "states such as Rajasthan raised the minimum wage from Rs 70 to Rs 100 in the last one year while some others doubled it during the period."(Prasad and Antony, 2009).
} 


\section{Workfare}

Since workfare is an important feature of poverty alleviation, it warrants a critical review. In doing so, the incentive aspects are examined below. ${ }^{6}$

The incentive case for workfare in poverty alleviation rests on two arguments. One is the screening argument, i.e. a work-requirement tends to exclude the non-poor (or, more generally, the relatively affluent). The other is the deterrent argument, i.e., the work-requirement does not deter poverty-reducing investments (say, in human capital). These are considered in turn below.

The screening argument is motivated by administrative difficulties in identifying the poor. Abilities are not directly observable. Although earnings could yield some clues, their estimates tend to be patchy and unreliable. Given these difficulties, self-selection mechanisms such as work-requirement are appealing. Under certain conditions, it can be shown that workrequirement is a cost-minimizing poverty alleviation strategy (as compared with uniform transfers). Assuming that the poor work in the labour market without any workfare scheme and that they can allocate their labour between agriculture and workfare, the work-requirement will reduce their earnings from elsewhere. It will thus necessitate larger transfers to get them out of poverty than those offered by the targeted intervention, with monetary transfer corresponding to the wage earnings under workfare, given that the latter would not lose the incentives to work in agriculture. This is the cost of self-selection through work-requirement; but there is also a cost reduction on account of lower transfers to the non-poor (as their incentive to masquerade as poor is weakened). There is a particular work-requirement which resolves this trade-off optimally, provided that the poor are a small fraction of the population and their earning potential is limited.

The deterrent argument takes a different form. Transfers reduce the returns to effort and thus induce individuals to choose a lower level of effort. This increases the number of poor, as also

\footnotetext{
${ }^{6}$ Workfare underpinned the 1834 Poor Law in England. The idea was that the conditions of the ablebodied pauper be the 'less-eligible'-desirable, agreeable, favourable-than that of the 'lowest class' of labourer (Himmelfarb, 1984, p.163). Further "It is only ....by making relief in all cases less agreeable than wages, that anything deserving the name of improvement can be hoped for" (Himmelfarb, 1984, p.165). For a review, see Gaiha, 2000, 2001, 2007, Gaiha and Imai, 2006, Jha et al. 2008, Jha, Bhattacharya, Gaiha, Shankar, 2009, Jha, et al., 2009a.
} 
the cost of poverty alleviation. Under certain conditions, however, workfare is optimal. There is a particular work-requirement which induces income-enhancing choices, provided that the share of the poor in the population is small, and their earning potential is low. ${ }^{7}$

As argued elsewhere, high NREGS wages undermine the screening and deterrent arguments which favour workfare. For example, in the context of the Employment Guarantee Scheme in Maharashtra, which started in the 1970s and served as the benchmark for NREGS, the hike in wages following a High Court directive in 1988 caused a worsening of targeting over the period 1979-89 (Gaiha, 2000, 2001, 2007). ${ }^{8}$ Although there were several reasons as sketched below, the hike in EGS wages was a key factor.

As the EGS wage exceeded the agricultural wage, exclusion of the non-poor (through a workrequirement) became harder and the poor were 'crowded out'. Simultaneously, given the budget constraint, there was 'rationing' of employment through delays in registration for employment and opening of new work-sites, and offer of less remunerative tasks. An issue then is whether the poor bore the brunt of it. In fact, they did. Delays in registration added to the gap between registration and offer of work, and discouraged the poor more than others, as the poor tend to live hand-to-mouth. Equally, if the distance to be travelled increases because of the restrictions on new work-sites, the less energetic poor in particular would be discouraged to participate in the scheme. Moreover, there is some evidence that over time corruption has increased. Given their limited network of relationships, however, the poor are typically at a greater disadvantage and thus more likely to be excluded or underpaid. Tightening of rural labour markets also resulted in the withdrawal of some poor from the EGS. Expansion of employment opportunities through the EGS in irrigated regions - mostly in sugarcane cutting — is a case in point. Although there are 'costs' of migration in the switch from agriculture to the EGS among others (e.g. disruption of family life), the compensations, such as an advance from the labour contractor, and timely and regular wage payments, would justify the expansion of the EGS.

\footnotetext{
${ }^{7}$ This summarises the exposition in Besley and Coate (1992). For a review, see Gaiha (2000, 2001, 2007), Gaiha and Imai (2006) and Jha et al. (2009a, b).

${ }^{8}$ These analyses are based on the ICRISAT panel survey of villages in Maharashtra.
} 


\section{Estimation of Excess Demand}

The NREGS website reports number of households who demanded work and number of jobs provided at the district level in 2007-08 and 2008-09.

As may be noted from Table 1, except for Bihar and Uttar Pradesh, nearly all or a very large majority of districts in the remaining four states had small or negligible gaps. In the next year, except for Madhya Pradesh and Tamil Nadu where the shares of districts with zero gap declined slightly, all other states recorded higher shares. Of particular significance is the sharp rise in Uttar Pradesh and Bihar.

Table 1

Actual Demand-Supply Gap under NREGS

\begin{tabular}{lcccccc}
\hline \multirow{2}{*}{ State } & \multicolumn{2}{c}{$\begin{array}{c}\text { No. of Districts with Demand and } \\
\text { Supply Data }\end{array}$} & \multicolumn{2}{c}{$\begin{array}{c}\text { No. of Districts with Zero } \\
\text { Demand-Supply Gap }\end{array}$} & \multicolumn{2}{c}{ \% of Districts with Zero Gap } \\
& $2007-08$ & $2008-09$ & $2007-08$ & $2008-09$ & $2007-08$ & $2008-09$ \\
\hline Andhra Pradesh & 19 & 22 & 19 & 22 & 100.00 & 100.00 \\
Bihar & 37 & 35 & 28 & 32 & 75.68 & 91.43 \\
Madhya Pradesh & 27 & 44 & 26 & 41 & 96.30 & 93.18 \\
Rajasthan & 12 & 31 & 10 & 31 & 83.33 & 100.00 \\
Tamil Nadu & 10 & 29 & 10 & 28 & 100.00 & 96.55 \\
Uttar Pradesh & 39 & 69 & 29 & 65 & 74.36 & 94.20 \\
Aggregate & 144 & 230 & 122 & 219 & 84.72 & 95.22 \\
\hline
\end{tabular}

Note: Aggregate refers to the total for the six states. The comparison between 2007-08 and 2008-09 is complicated by the fact that number of districts covered under the NREGS rose sharply over the period in question.

As noted earlier, however, given the large scale fudging of muster rolls, corruption in the payment of wages, and inflated records of jobs provided, these estimates of excess demand cannot be taken at face value. Using basic economic theory, the demand and supply estimates are refined and purged to some extent of measurement errors. We do so in the following way.

$$
\begin{aligned}
& \log (N R E G S)^{d}{ }_{i t}=\beta_{0}+\beta_{1} N_{R E G W A G E}{ }_{i t}+\beta_{2}(N R E G W A G E)^{2}{ }_{i t}+\beta_{3} L_{O R E N Z}{ }_{i t}+ \\
& \beta_{4}(\text { LORENZ })^{2}{ }_{\text {it }}+\beta_{5} \text { bimaru }+\varepsilon_{1 i}
\end{aligned}
$$


A brief justification for equation (1) is that the demand for jobs is hypothesised to vary with NREGS wages relative to agricultural wage rates in district i and year t. ${ }^{9} \log (N R E G S)^{d}{ }_{i t}$ stands for logarithm of the demand for NREGS jobs in district $i$ and year $t$, and d denotes demand. The higher the NREGS wage relative to the agricultural wage, the greater is the demand for NREGS jobs. If NREGS is considered an 'inferior' good or option, given the strenuous and unskilled nature of work (e.g., digging of earth and carrying of headloads of it), the positive relationship between demand and NREGS wages would weaken at higher levels. Hence we have used both the level and square of NREGS wages. Unfortunately, as we did not have easy access to district level agricultural wage rates, we have used NREGS wage as a proxy for the (relative) NREGS wage. We have also posited a non-linear relationship between the transformed NREGS demand and income inequality measured by the Gini/Lorenz coefficient, and its square. Specifically, controlling for the effects of other variables, under certain conditions, the higher the inequality, the fewer will be rewarding employment opportunities and the higher will be NREGS demand. Other things being equal, the more economically backward a state is (specifically, whether it is one of the BIMARU states ${ }^{10}$ ), the higher will be demand for guaranteed employment of the NREGS kind. Given the results of this specification, we obtain more refined estimates of demand at the district level. $a_{1: t}$ is an independent and identically distributed (i.i.d.) error term.

Jobs provided or NREGS supplies are/is specified as follows. Consider NREGS ${ }^{S}$ it in 2008-09. $\log (N R E G S)^{s}{ }_{i t}$ is logarithm of the supply of NREGS jobs in district $\mathrm{i}$, and year $\mathrm{t}$ and $\mathrm{s}$ denotes supply. It is posited that the supply of jobs is determined by the state revenue-expenditure deficit in the preceding and current years, and the amount available for NREGS. Some elaboration would be useful. First, it may be noted that the bulk of NREGS funds come from the centre (typically 90 per cent or more). Hence state revenue-expenditure deficit does not have a decisive role in determining supply. Nevertheless, it would be erroneous to conclude that state deficits are inconsequential. Given their parlous state, it is arguable that a succession of state deficits may dilute the NREGS. So funds available at the district level are not influenced so much by state

\footnotetext{
${ }^{9}$ It is noted that because we take the first lag in equation (2) below and focus on the demand and supply and their gap for NREGS in each year, we estimate equations (1), (2) and (3) by (robust) ordinary least squares (OLS hereafter) for the cross-sectional data in 2007-08 and 2008-09 separately, rather than using the panel data or pooled regression with year or district effects. We keep $t$ in all the equations to clarify the difference of $t$ and $t-1$.

${ }^{10}$ BIMARU states are Bihar, Madhya Pradesh, Rajasthan, and Uttar Pradesh.
} 
deficits as by allocation criteria used. But their interaction may weaken the constraining effect of revenue deficit. ${ }^{11}$

An algebraic representation of the supply of NREGS is given below:

$$
\log (N R E G S)^{s}{ }_{k i t}=\delta+\delta_{1} \text { Revenue }_{k t-1}+\delta_{2} \text { Funds }_{i t}+\delta_{3} \text { Revenue }_{k t-1} \times \text { Funds }_{i t}+\varepsilon_{2 i t}
$$

where RevenueD refers to revenue deficit, $\mathrm{k}$ denotes state, i denotes district, $\mathrm{t}$ denotes year, and Funds represent amount available at the district level. The state level variable, RevenueD takes the same value for different districts within a state. $\varepsilon_{2 i t}$ is an i.i.d error term.

After predicting demand for and supply of NREGS at the district level separately for 2007-08 and 2008-09, we analyse the variation in excess demand at the district level. A presumption here is that small deviations from demand are not an indication of failure. Indeed, given the nature of demand and lack of precision in measuring it, in general, it is plausible that demand is underreported because of continuing limited awareness of such interventions in remote areas. In that case, excess of supply over demand is more desirable than excess of demand over a certain range.

Whether excess demand varies with poverty is examined with the help of equation (3). The latter are obtained from the $61^{\text {st }}$ round of the NSS for 2004-05.

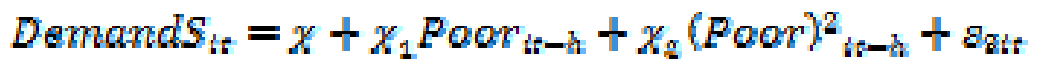

where DemandS $S_{\text {it }}$ denotes excess demand in ith district and year $\mathrm{t}$, and Poor $_{\mathrm{it}-\mathrm{h}}$ represents the headcount index, $(\text { Poor })^{2}{ }_{i t h}$ its square. h denotes the number of lags (i.e. 3 or 4). $\varepsilon_{\text {st }}$ is an i.i.d. error term. We have experimented with different samples for 2007-08 and 2008-09.

In the final specification, we examine the likely impact of sharp spikes in NREGS wages in a few states on the Consumer Price Index for Agricultural Labourers in Rural Areas (CPIAL). As we did not have easy access to NREGS wages for two years while agricultural wages were

\footnotetext{
${ }^{11}$ Ideally, state deficits and amounts allocated should be instrumented, but we refrained from it because our data would not provide valid instruments to satisfy exclusion restrictions. So there may be some (simultaneity) bias in their coefficients and a cautious interpretation is necessary.
} 
available for two consecutive years but at the state level, we preferred the latter as a proxy for NREGS wages. Other explanatory variables used are CPIAL in the previous year, state revenueexpenditure deficit, its square, and funds available. Algebraically,

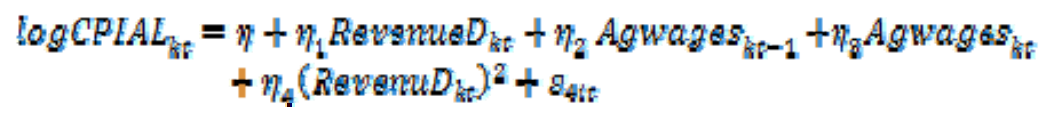

where $\log C P I A L_{s t}$ is the CPIAL index for state $\mathrm{k}$ and year $\mathrm{t}$, Reverue $\mathbb{L}_{\mathrm{st}}$ denotes state revenue

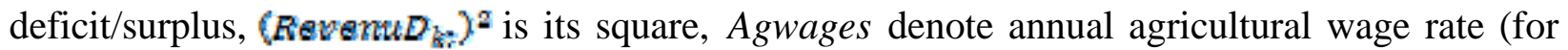
males) in 2005 and 2006, respectively, and $\varepsilon_{4 k t}$ is the iid error term.

\section{Results}

\section{(a) Determinants of Demand and Supply}

We shall consider NREGS demand estimation first, followed by supply estimation. Their implications for excess demand are then analysed, followed by whether excess demand varies with district poverty and whether hikes in NREGS wages are inflationary.

Table 2 presents the regression results of demand equation. As hypothesised, the higher the NREGS wage, the greater was the demand for it in 2007-08 as in Case A of Table 2. However, the effect of the square of NREGS wage was negative and significant, suggesting higher valuation of leisure beyond a certain NREGS wage. The greater the income inequality (measured by the Gini coefficient or Lorenz ratio), the greater was the demand for the NREGS. If income inequality is a manifestation of inequality in physical and human capital, it may imply oligopsonistic labour markets and lower employment and/or wages. ${ }^{12}$ The coefficient of the square of the Gini was, however, negative and significant. It may be conjectured that this is consistent with a floor to agricultural employment and wage rate. ${ }^{13}$ Controlling for these effects, the demand was higher in districts belonging to BIMARU states. The overall specification is validated by the $\mathrm{F}$ test.

\footnotetext{
${ }^{12}$ For some illustrative evidence, see Gaiha (1995).

${ }^{13}$ See Jha et al. (2009b) for recent evidence on nutrition-poverty trap in rural India.
} 
Table 2 Determinants of NREGS Demand

(Dep. Variable: log of hh employment demand (households which demanded employment)

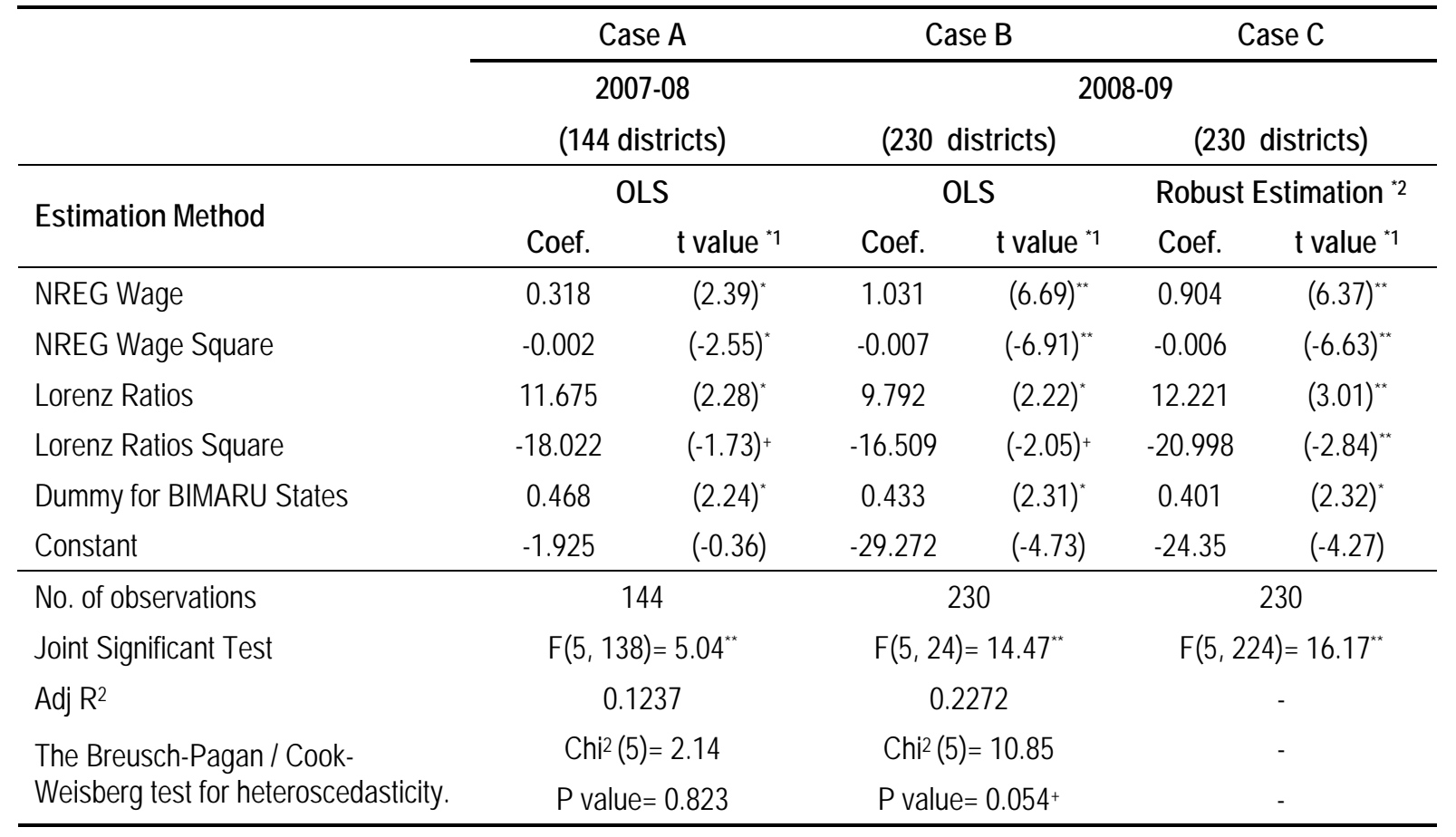

Notes: $1 .{ }^{*}=$ statistically significant at $1 \%$ level. ${ }^{*}=$ significant at $5 \%$ level. $+=$ significant at $10 \%$ level.

2. Robust estimator is based on the Huber-White heteroskedasticity-consistent covariance matrix estimator.

Similar results are obtained with the data for 2008-09. We report the results of OLS and robust estimation in Case B and Case C, respectively. NREGS demand is positively related to the wage rate and negatively to its square; the effect of the Gini is again positive and that of its square negative; and, finally, districts in BIMARU states had higher demand. But the coefficients differ in their magnitudes. For example, the effect of NREGS wage rate was considerably higher in 2008-09, as also that of the Gini. Note also that the sample for 2008-09 is considerably larger than that for 2007-08.

Turning to supply of NREGS jobs, note first that the ordinary least squares estimates for 2007-08 suffer from heteroscedasticity (Case A of Table 3). Accordingly, we shall comment on the robust regression results in Case B of Table 3. The state revenue deficit in 2006-07 has a constraining effect on NREGS supply, while its interaction with amount available does not have a significant 
effect. Given the revenue deficits, funds available at the district level, however, have a positive effect. The F-ratio is significant, validating the overall specification. ${ }^{14}$

The robust regression results for NREGS supply in 2008-09 reported in the last column (Case D) of Table 3 differ in some ways. First, state revenue deficit in 2007-08 had a constraining effect while its interaction with amount available had a positive effect on the provision of NREGS jobs. The effect of availability of funds was significant and positive.

${ }^{14}$ In an alternative specification, the lagged revenue deficit and $\Delta$ deficit were used as explanatory variables (the latter as an alternative to current deficit). The latter, however, does not have a significant effect for year 2007-08, as shown in (Case A) of Annex Table A.4. However, the results for 2008-09 differ. Specifically, for the sample of 230 districts, while the revenue deficit has a negative effect on the supply of NREGS jobs, the $\Delta$ deficit has a significant and positive effect. It is not self-evident why this is so. With the sample of 142 districts in 2008-09, however, the coefficient of revenue deficit remains significantly negative, while that of $\Delta$ deficit ceases to be significant. For details, see (Case B) of Table A. 4 in the Annex. 
Table: 3 Determinants of NREGS Supply

(Dep. Variable: log of hh employment provided (households which demanded employment)

\begin{tabular}{|c|c|c|c|c|c|c|c|c|}
\hline \multirow{4}{*}{ Estimation Method } & \multicolumn{2}{|c|}{ Case A } & \multicolumn{2}{|c|}{ Case B } & \multicolumn{2}{|c|}{ Case C } & \multicolumn{2}{|c|}{ Case D } \\
\hline & \multicolumn{4}{|c|}{$\begin{array}{c}2007-08 \\
\text { (144 districts) }\end{array}$} & \multicolumn{4}{|c|}{$\begin{array}{c}\text { 2008-09 } \\
\text { (230 districts) }\end{array}$} \\
\hline & \multicolumn{2}{|c|}{ OLS } & \multicolumn{2}{|c|}{ Robust Estimation *2 } & \multicolumn{2}{|c|}{ OLS } & \multicolumn{2}{|c|}{ Robust Estimation *2 } \\
\hline & Coef. & t value ${ }^{*_{1}}$ & Coef. & t value ${ }^{* 1}$ & Coef. & t value ${ }^{* 1}$ & Coef. & t value ${ }^{*}$ \\
\hline Revenue Surplus/ Deficit 2006-07 & -0.000031 & $(-0.7)$ & 0.00008 & $(-1.93)^{*}$ & - & - & - & - \\
\hline Revenue Surplus/ Deficit 2007-08 & - & - & - & - & -0.0002 & $(-7.71)^{\star *}$ & -0.00019 & $(-9.29)^{* *}$ \\
\hline Fund available in 2007-08 (Lakh) & 0.000091 & $(10.3)^{*+*}$ & 0.000078 & $(9.52)^{*+*}$ & - & - & - & \\
\hline Fund available in 2008-09 (Lakh) & - & - & - & - & 0.0000577 & $(8.93)^{*+}$ & 0.0000512 & $(9.79)^{\text {*k }}$ \\
\hline $\begin{array}{l}\text { Interaction of Revenue Surplus/ } \\
\text { Deficit } 2006-07 \text { and Fund available } \\
\text { in 2007-08 }\end{array}$ & -0.0000000014 & $(-0.21)$ & -0.0000000035 & $(0.58)$ & - & - & - & - \\
\hline $\begin{array}{l}\text { Interaction of Revenue Surplus/ } \\
\text { Deficit } 2007-08 \text { and Fund available } \\
\text { in 2008-09 }\end{array}$ & - & - & & & 1.4E-08 & $5.02^{* *}$ & 1.13E-08 & $5.03^{\text {*t }}$ \\
\hline Constant & 11 & 142.48 & 11.144 & 154.11 & 11.067 & 117.51 & 11.23 & 147.13 \\
\hline No. of observations & \multicolumn{2}{|c|}{144} & \multicolumn{2}{|c|}{144} & \multicolumn{2}{|c|}{230} & \multicolumn{2}{|c|}{230} \\
\hline Joint Significant Test & \multicolumn{2}{|c|}{$F(3,140)=49.55^{\text {t* }}$} & \multicolumn{2}{|c|}{$F(3,140)=14.47^{* *}$} & \multicolumn{2}{|c|}{$F(3,226)=122.89^{4 *}$} & \multicolumn{2}{|c|}{$F(3,226)=160.99^{* *}$} \\
\hline Adj $R^{2}$ & \multicolumn{2}{|c|}{0.5046} & \multicolumn{2}{|c|}{-} & \multicolumn{2}{|c|}{0.6149} & \multicolumn{2}{|c|}{-} \\
\hline $\begin{array}{l}\text { The Breusch-Pagan / Cook- } \\
\text { Weisberg test for }\end{array}$ & \multicolumn{2}{|c|}{$\mathrm{Chi}^{2}(3)=24.14^{\star \star}$} & \multicolumn{2}{|c|}{-} & \multicolumn{2}{|c|}{$\mathrm{Chi}^{2}(3)=35.19^{\text {tk }}$} & \multicolumn{2}{|c|}{-} \\
\hline heteroscedasticity. & \multicolumn{2}{|c|}{$P$ value $=0.00$} & \multicolumn{2}{|c|}{-} & \multicolumn{2}{|c|}{$P$ value $=0.00$} & \multicolumn{2}{|c|}{-} \\
\hline
\end{tabular}

Notes: $1 .{ }^{*}=$ statistically significant at $1 \%$ level. ${ }^{*}=$ significant at $5 \%$ level. $+=$ significant at $10 \%$ level.

2. Robust estimator is based on the Huber-White heteroskedasticity-consistent covariance matrix estimator. 


\section{(b) Excess Demand}

Let us now turn to excess demand in 2007-08 and 2008-09. We construct estimates of excess demand first for a common sample of 142 districts in both years. Table 4 groups districts under four categories: where excess supply persisted, where excess demand persisted, where excess demand in 2007-08 turned into excess supply in 2008-09, and where excess supply in 2007-08 turned into excess demand in 2008-09. The results point to some significant changes. Supply exceeded demand in a majority of districts in Rajasthan, Tamil Nadu and Andhra Pradesh. In sharp contrast is Bihar where not even one district had more supply than demand. As shown in the column labelled 'Persistent Excess Demand', a vast majority of districts in Bihar (about 83 per cent) were in this category, illustrating under-provision of NREGS jobs. Andhra Pradesh, Tamil Nadu, Madhya Pradesh and Uttar Pradesh also had well over one-quarter of the districts in this category. Yet another indicator of how these states performed is proportion of districts where excess demand in 2007-08 turned into excess supply in 2008-09. Interestingly, about 17 per cent of the districts in Bihar are grouped in this category and about 11 per cent in Andhra Pradesh, implying that non-negligible proportions registered an improvement in the sense that there was a positive response to prevailing excess demand. But a considerably higher proportion of districts in the aggregate sample (i.e. allIndia in the restricted sense of total districts in the sample) recorded reversal of excess supply in 2007-08 to excess demand in 2008-09. In this category, largest proportion was found in Uttar Pradesh, followed by Madhya Pradesh and Rajasthan.

Table 4

Distribution of Excess Demand in 2007-08 \& 2008-09

\begin{tabular}{|c|c|c|c|c|c|}
\hline \multirow[b]{2}{*}{ States } & \multicolumn{4}{|c|}{ \% Districts where } & \multirow[b]{2}{*}{$\begin{array}{l}\text { Total } \\
\text { Number } \\
\text { of Districts } \\
\text { Covered }\end{array}$} \\
\hline & $\begin{array}{c}\text { Persistent } \\
\text { Excess Supply }\end{array}$ & $\begin{array}{c}\text { Persistent } \\
\text { Excess Demand }\end{array}$ & $\begin{array}{c}\text { Excess Demand in } \\
2007-08 \\
\text { but } \\
\text { Excess Supply } \\
\text { in 2008-09 }\end{array}$ & $\begin{array}{c}\text { Excess Supply in } \\
2007-08 \\
\text { but } \\
\text { Excess Demand } \\
\text { in 2008-09 } \\
\end{array}$ & \\
\hline Andhra Pradesh & 52.63 & 31.58 & 10.53 & 5.26 & 19 \\
\hline Bihar & 0.00 & 82.86 & 17.14 & 0.00 & 35 \\
\hline Madhya Pradesh & 51.85 & 29.63 & 0.00 & 18.52 & 27 \\
\hline Rajasthan & 66.67 & 16.67 & 0.00 & 16.67 & 12 \\
\hline Tamil Nadu & 60.00 & 30.00 & 0.00 & 10.00 & 10 \\
\hline Uttar Pradesh & 38.46 & 28.21 & 0.00 & 33.33 & 39 \\
\hline Aggregate & 37.32 & 41.55 & 5.63 & 15.49 & 142 \\
\hline
\end{tabular}


In order to make an overall assessment of performance, let us turn to Table 5 (a). The mean excess demand in 2007-08 was -8.20 and it doubled in 2008-09, implying that in the aggregate the gap in (absolute value) rose considerably. This suggests that NREGS became less responsive to demand in 2008-09. Also, the range of excess demand (maximum and minimum values) was wider in 2008-09. These evidences suggest a relative deterioration in the performance of NREGS. This conclusion is further corroborated by state-level results.

Table 5

(a) Excess Demand in 2007-08 \& 2008-09: with 142 common districts

\begin{tabular}{lcccccc}
\hline States & \multicolumn{3}{c}{$\mathbf{2 0 0 7 - 0 8}$} & \multicolumn{3}{c}{$\mathbf{2 0 0 8 - 0 9}$} \\
& $\begin{array}{c}\text { Mean } \\
(\mathbf{0 0 0})\end{array}$ & $\begin{array}{c}\text { Max } \\
\mathbf{( 0 0 0 )}\end{array}$ & $\begin{array}{c}\text { Min } \\
\mathbf{( 0 0 0 )}\end{array}$ & $\begin{array}{c}\text { Mean } \\
\mathbf{( 0 0 0 )}\end{array}$ & $\begin{array}{c}\text { Max } \\
(\mathbf{0 0 0})\end{array}$ & $\begin{array}{c}\text { Min } \\
(\mathbf{0 0 0})\end{array}$ \\
\hline Andhra Pradesh & -21.69 & 74.49 & -127.63 & -21.74 & 47.47 & -125.80 \\
Bihar & 25.65 & 63.97 & -10.86 & 59.46 & 88.82 & 6.89 \\
Madhya Pradesh & -21.94 & 117.99 & -192.47 & -47.53 & 48.70 & -204.47 \\
Rajasthan & -65.15 & 57.43 & -416.97 & -125.13 & 13.75 & -435.46 \\
Tamil Nadu & -30.98 & 23.31 & -138.28 & -24.30 & 10.83 & -101.61 \\
Uttar Pradesh & 0.87 & 38.05 & -61.85 & -23.68 & 19.00 & -124.35 \\
Aggregate & -8.20 & 117.99 & -416.97 & -16.08 & 88.82 & -435.46 \\
\hline
\end{tabular}

(b) Excess Demand in 2007-08 \& 2008-09: with 144 districts in 2007-08 and 230 districts in 2008-09

\begin{tabular}{lcccccc}
\hline \multicolumn{1}{c}{ States } & \multicolumn{3}{c}{$\mathbf{2 0 0 7 - 0 8}$} & \multicolumn{3}{c}{$\mathbf{2 0 0 8 - 0 9}$} \\
& $\begin{array}{c}\text { Mean } \\
\mathbf{( 0 0 0 )}\end{array}$ & $\begin{array}{c}\text { Max } \\
\mathbf{( 0 0 0 )}\end{array}$ & $\begin{array}{c}\text { Min } \\
\mathbf{( 0 0 0 )}\end{array}$ & $\begin{array}{c}\text { Mean } \\
\mathbf{( 0 0 0 )}\end{array}$ & $\begin{array}{c}\text { Max } \\
\mathbf{( 0 0 0 )}\end{array}$ & $\begin{array}{c}\text { Min } \\
\mathbf{( 0 0 0 )}\end{array}$ \\
\hline Andhra Pradesh & -21.69 & 74.49 & -127.63 & -13.01 & 47.47 & -125.80 \\
Bihar & 24.71 & 63.97 & -10.86 & 59.46 & 88.82 & 6.88 \\
Madhya Pradesh & -21.94 & 117.99 & -192.47 & -14.54 & 52.90 & -204.5 \\
Rajasthan & -65.15 & 57.43 & -416.97 & -89.0 & 64.05 & -435.45 \\
Tamil Nadu & -30.98 & 23.31 & -138.28 & -10.60 & 21.20 & -101.6 \\
Uttar Pradesh & 0.87 & 38.05 & -61.85 & -5.44 & 29.61 & -124.35 \\
Aggregate & -7.97 & 117.99 & -416.97 & -9.95 & 88.82 & -435.5 \\
\hline
\end{tabular}

In all six states, there was a widening of excess demand, regardless of whether initially it was positive or negative.

Two illustrations suffice. In Bihar, excess demand in 2007-08 was over 25000 in 2007-08, and it rose to about 60, 000 in 2008-09; in Uttar Pradesh, by contrast, it was negligible in 2007-08 but turned negative in 2008-09 $(-24,000)$. 
Does the performance of NREGS change with the larger sample of 230 districts in 2008-09? In Table 5 (b), excess demand (in absolute value) rose but by a small amount-more specifically, excess supply increased by about 2000. Also, there were some significant changes at the state level. In Andhra Pradesh, Madhya Pradesh and Tamil Nadu, the gap narrowed substantially. Bihar and Uttar Pradesh -especially the former- witnessed a sharp widening of the gap. ${ }^{15}$

Some of the changes in the distribution of excess demand are illustrated graphically. For convenience of exposition, we have used normalised excess demand. Figures $1 \mathrm{a}$ and $1 \mathrm{~b}$ are constructed for 144 and 142 districts in 2007-08 (the latter overlap with the corresponding subset in the sample for 2008-09), respectively. ${ }^{16}$

As may be noted from the first graph (1a), there is a large concentration of districts in the neighbourhood of 0 . With 2 fewer districts, the distribution changes somewhat in its peakedness, as to the immediate right of 0 , the relative frequency of districts falls sharply. With the same 142 districts, the distribution of excess demand in 2008-09 becomes more concentrated in the neighbourhoods of 0 . The contrast with the distribution based on 230 districts in 2008-09 is somewhat striking in so far as the concentration in a small range of values around 0 is lower. ${ }^{17}$

Further investigations focus on the relationship between (normalised) monthly per capita expenditure and (normalised) excess demand. ${ }^{18}$ Figure 3a is based on samples of 142 districts in 2007-08 and 230 districts 2008-09. Both curves corroborate a non-linear relationship-the gaps rise over similar ranges of income to the left of 0 and then fall over ranges to the right of 0 and rise again. What is also significant is that at MPCE lower than 0 the gaps were larger in 2008-09 but at higher MPCEs these were lower than corresponding gaps in 2007-08. A similar pattern is reflected in Figure 3b, based on the same 142 districts in 2007-08 and 200809 except that the gaps are much larger at MPCEs larger than 0 and negligible to its left.

\footnotetext{
${ }^{15}$ Table A.3 in the Annex gives t-tests of the mean differences in excess demand over the period 2007-09. While the means are significantly different only in Bihar, and in Bihar and Uttar Pradesh, respectively, depending on whether the common sample of 142 districts or the larger sample of 230 districts is used. These results, however, do not necessarily invalidate the comparisons reported here as mean differences could be suppressed by high within-group variability.

${ }^{16}$ Note that of the 144 districts for which data are available, 142 are common to both 2007-08 and 2008-09 samples.

${ }^{17}$ For a more detailed comment, see the Annex.

${ }^{18}$ The normalization is done on the basis of means and standard deviations of aggregate samples for 2007-08 and 2008-09.
} 


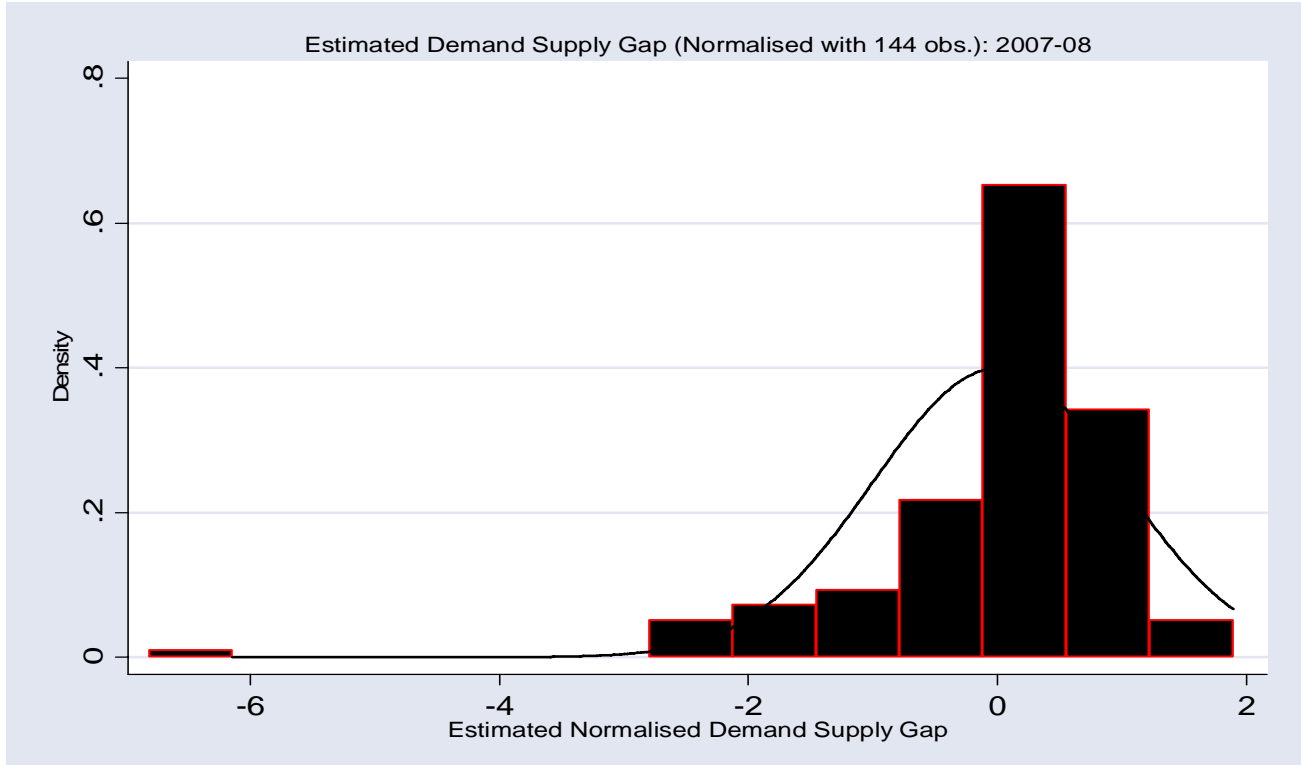

Figure 1a All-India Distribution of Excess Demand in 2007-08 (144 districts)

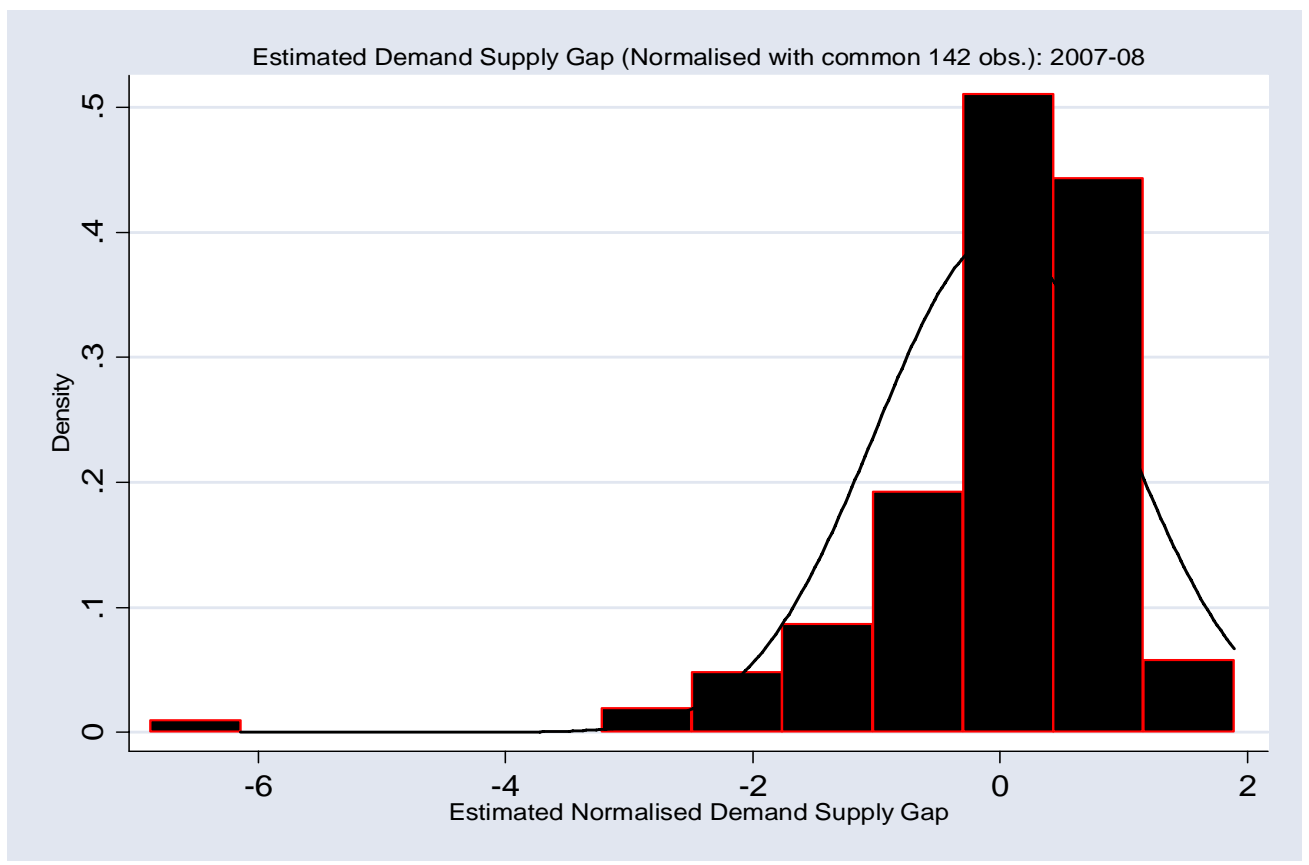

Figure 1b All-India Distribution of Excess Demand in 2007-08 (142 districts) 


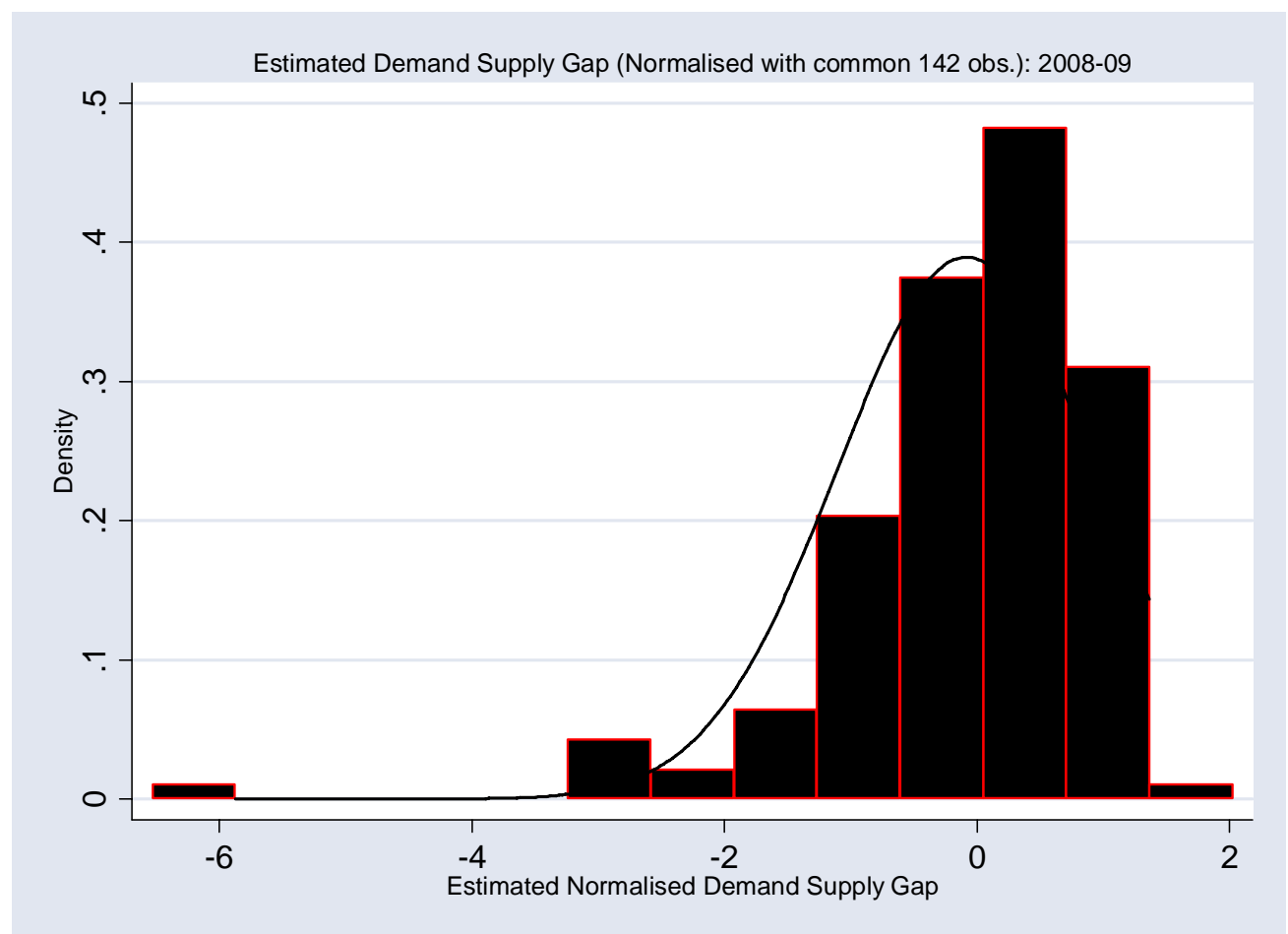

Figure 2a All-India (Normalised) Distribution of Excess demand (with 142 Districts) 2008-09

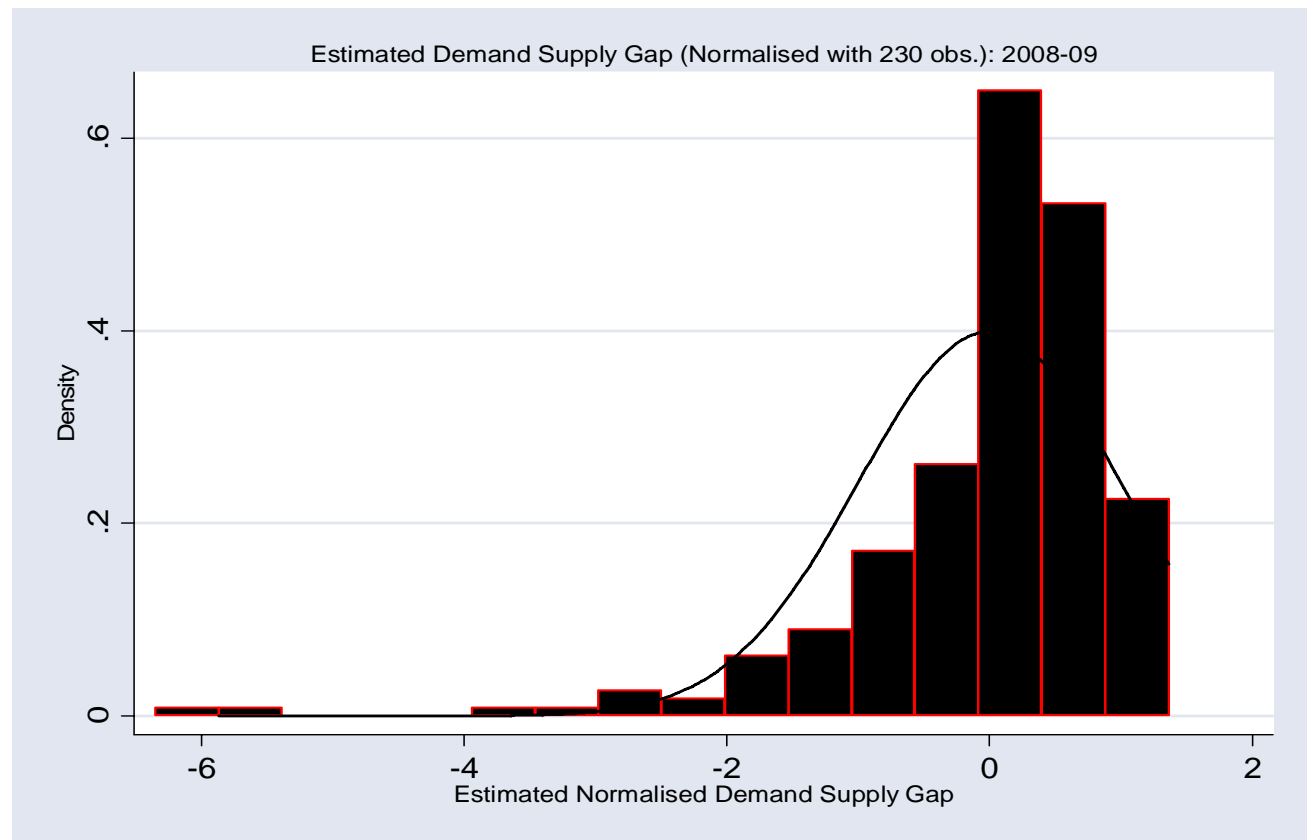

Figure 2b All-India (Normalised) Distribution of Excess Demand (with 230 Districts) 2008-09 


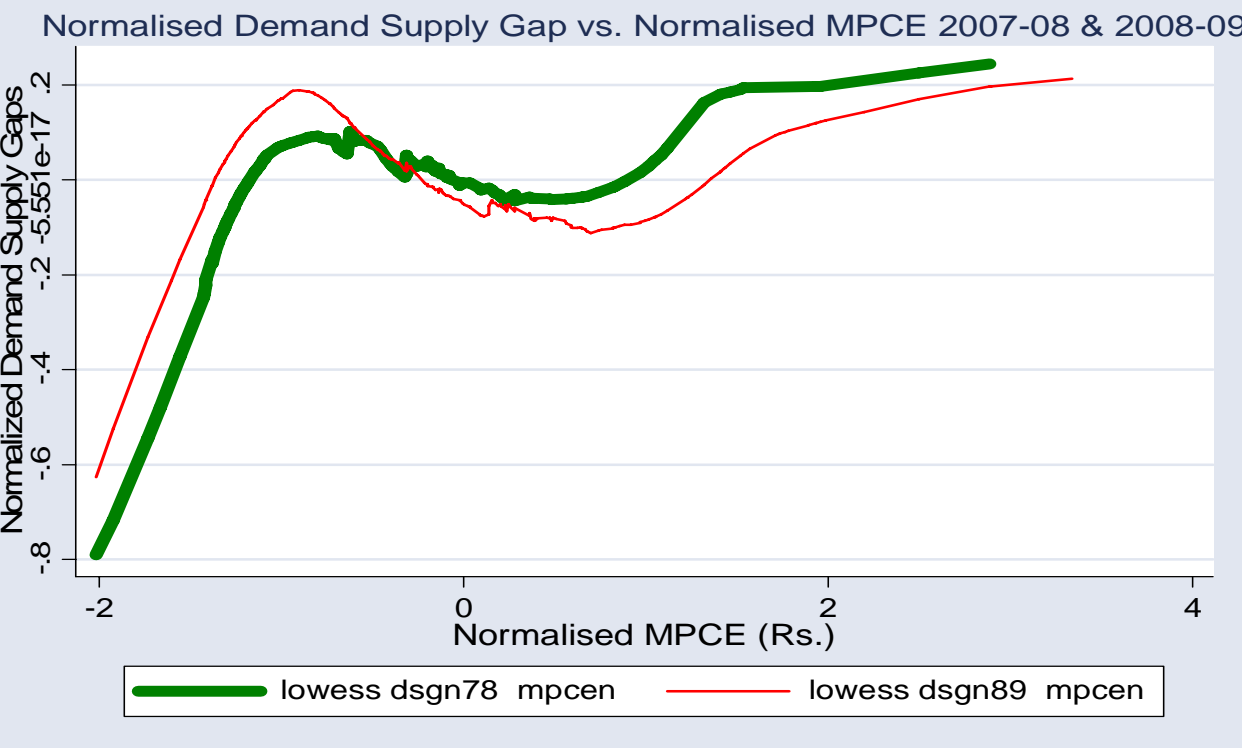

Figure 3a (Normalised) Excess Demand by (Normalised) MPCE (142 Districts in 2007-08 and 230 Districts in 2008-09)

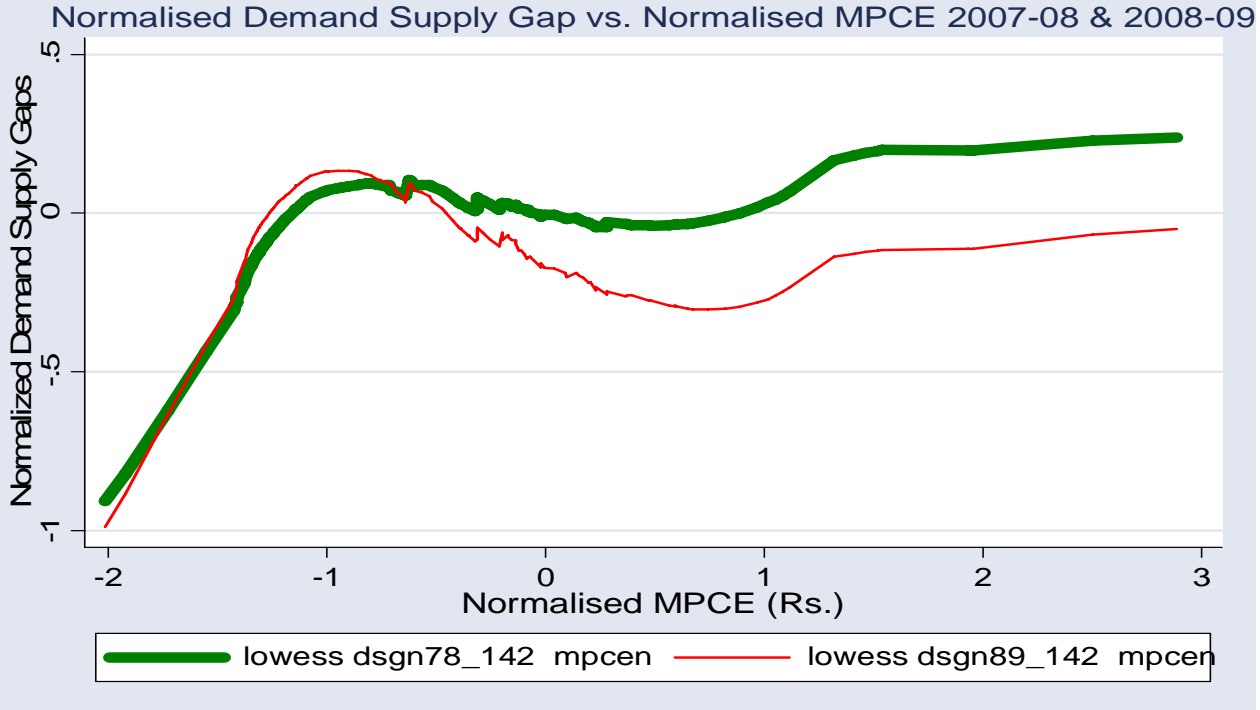

Figure 3b (Normalised) Excess Demand by (Normalised) MPCE (142 Districts) 


\section{Is Excess Demand Sensitive to Poverty?}

V.

Using estimated excess demand and equation 3, we analyse whether it is sensitive to the district level poverty head-count ratio in 2004-05, the most recent poverty estimates. The results based on samples for 2007-08 and 2008-09 are given in Table 6.

Let us first consider the robust regression results for the samples of 144 and 142 districts in 2007-08 (Case A and Case B). Case B is tried for only 142 states which have the common data in both 2007-08 and 2008-09. In both cases, excess demand is positively related to headcount ratios and inversely to the square of the latter. This suggests a robust non-linear relationship, implying that excess demand in 2007-08 responded positively to excess demand but at a diminishing rate. As the coefficient of the headcount is large, it is plausible to maintain that that the positive response is likely to dominate.

Turning to the robust regression results for samples of 230 and 142 districts in 2008-09 presented in Case C and Case D of Table 6, there are a few differences. First, the results for 230 districts are not so robust-especially the coefficient of the square of the poverty index. Also, that of the poverty index is smaller than the corresponding coefficient for 2007-08, implying slower adjustment in the districts that were covered in 2008-09 but not in 2007-08. However, the robust regression results for the common 142 districts in 2008-09 confirm the non-linearity between excess demand and poverty. In fact, the coefficient of poverty is larger in value than the corresponding coefficient in 2007-08, suggesting greater responsiveness in districts that were covered in both 2007-08 and 2008-09. Broadly, this could be attributed to greater awareness among the poor of their entitlement. 
Table 6 Poverty (2004-05) as a Determinant of Estimated Excess Demand (Robust Estimator) Excess Demand (Dep. Variable: Estimated Demand Supply Gap 2007-08 or 2008-09)

\begin{tabular}{|c|c|c|c|c|c|c|c|c|}
\hline & \multicolumn{2}{|c|}{ Case A } & \multicolumn{2}{|c|}{ Case B } & \multicolumn{2}{|c|}{ Case C } & \multicolumn{2}{|c|}{ Case D } \\
\hline & \multicolumn{4}{|c|}{ 2007-08 } & \multicolumn{4}{|c|}{ 2008-09 } \\
\hline & \multicolumn{2}{|c|}{ (144 districts) } & \multicolumn{2}{|c|}{ (142 Common Districts) } & \multicolumn{2}{|c|}{ (230 districts) } & \multicolumn{2}{|c|}{ (142 Common Districts) } \\
\hline \multirow[t]{2}{*}{ Estimation Method } & \multicolumn{2}{|c|}{ Robust Estimation *2 } & \multicolumn{2}{|c|}{ Robust Estimation *2 } & \multicolumn{2}{|c|}{ Robust Estimation *2 } & \multicolumn{2}{|c|}{ Robust Estimation *2 } \\
\hline & Coef. & t value ${ }^{* 1}$ & Coef. & t value ${ }^{* 1}$ & Coef. & t value ${ }^{{ }_{1}}$ & Coef. & t value ${ }^{*_{1}}$ \\
\hline Proportion of Poor & 2159.176 & $(2.9)^{\star \star}$ & 2314.86 & $(3.04)^{*+}$ & 1164.17 & $(1.76)^{+}$ & 2249.701 & $(2.2)^{+}$ \\
\hline Square of Proportion of Poor & -27.658 & $(-2.8)^{*+}$ & -30.261 & $(-2.94)^{* *}$ & -14.947 & $(-1.59)$ & -26.651 & $(-1.93)^{+}$ \\
\hline Constant & -25513.6 & $(-2.12)$ & -26892 & $(-2.22)$ & -12625.1 & $(-1.26)$ & -42533.5 & $(-2.62)$ \\
\hline No. of observations & \multicolumn{2}{|c|}{144} & \multicolumn{2}{|c|}{142} & \multicolumn{2}{|c|}{230} & \multicolumn{2}{|c|}{142} \\
\hline Joint Significant Test & \multicolumn{2}{|c|}{$F(2,140)=4.22^{*}$} & \multicolumn{2}{|c|}{$F(2,139)=4.63^{*}$} & \multicolumn{2}{|c|}{$F(2,227)=1.63$} & \multicolumn{2}{|c|}{$F(2,139)=2.69^{+}$} \\
\hline
\end{tabular}

Notes: $1 .{ }^{\star *}=$ statistically significant at $1 \%$ level. *= significant at $5 \%$ level. $+=$ significant at $10 \%$ level.

2. Based on robust estimator based on the Huber-White heteroskedasticity-consistent covariance matrix estimator. 


\section{NREGS Wage and CPIAL}

In this section, our focus is on whether hikes in NREGS wages are likely to be inflationary. For lack of easy access to district level wage rates, we have used agricultural wage rates as a proxy for NREGS wage rates. Both OLS and robust regressions are applied to the district level crosssectional data in 2006-07 where Log of CPIAL in 2006-07 is estimated by revenue surplus/ deficit in 2006-07 and its square, average agricultural wage in 2005, and average agricultural wage in 2006, respectively. The results are given in Table 7.

Although homoscedasticity is not rejected at the 5 per cent level, we shall comment briefly on the robust regression results as well. In the OLS results, agricultural wage (lagged by one year) has a significant negative effect on CPIAL while the contemporaneous wage has a positive effect. None of the remaining variables have significant effects. The robust regression results, however, differ. First, revenue deficit has a significant positive effect on CPIAL, as also the square of the deficit. So, higher deficits are inflationary. Given the negative effect of agricultural wage (lagged by one year), the higher contemporaneous wage has a positive effect. Altogether thus higher wages are inflationary.

In sum, to the extent that NREGS and agricultural wage rates move in tandem, our analysis suggests that controlling for other factors, hikes in NREGS wages may have inflationary effects.

Further, as the correlation coefficient between agricultural wage rates for 2005 and 2006 is very high (0.9979), we have also used an alternative specification in which we retain average agricultural wage for the lagged year and replace the average agricultural wage for 2006 with delta agricultural wage rate. The results are given in Cases $C$ and $D$ of Table 7 and going by the robust regression results in Case $\mathrm{C}$, it follows that while CPIAL is negatively related to agricultural wage in 2005; it is positively related with delta agricultural wage rate.

Thus, again given the significance of coefficient of the later, the inflationary potential of higher agricultural wage rate (a proxy for delta NREGS wage rate) can not be ruled out. 
Table 7 Determinants of CPIAL: State wise 2006-07

Dep. Variable: CPIAL in 2006-07

\begin{tabular}{|c|c|c|c|c|c|c|c|c|}
\hline \multirow{3}{*}{ Estimation Method } & \multicolumn{2}{|c|}{ Case A } & \multicolumn{2}{|c|}{ Case B } & \multirow{2}{*}{\multicolumn{2}{|c|}{$\begin{array}{c}\text { Case C } \\
\text { Alternative Specification } \\
\text { OLS }\end{array}$}} & \multirow{2}{*}{\multicolumn{2}{|c|}{$\begin{array}{c}\text { Case D } \\
\text { Alternative Specification } \\
\text { Robust Estimation }\end{array}$}} \\
\hline & \multicolumn{2}{|c|}{ oLs } & \multicolumn{2}{|c|}{ Robust Estimation } & & & & \\
\hline & Coef. & t value $^{*_{1}}$ & Coef. & t value ${ }^{*_{1}}$ & Coef. & t value ${ }^{x_{1}}$ & Coef. & t value ${ }^{x_{1}}$ \\
\hline $\begin{array}{l}\text { Revenue Surplus/ Deficit 2006-07 (in } \\
\text { Rs. Crore) }\end{array}$ & 0.000000483 & $(0.07)$ & 0.00000603 & $(2.73)^{*+*}$ & 0.000000483 & $(0.07)$ & 0.00000603 & $(2.73)^{*+*}$ \\
\hline Average Agricultural Wage 2005 (LM) & -0.009 & $(-1.92)^{+}$ & -0.013 & $(-7.93)^{\star \star}$ & 0.0003 & $(0.77)$ & -0.000494 & $(-2.5)^{\star}$ \\
\hline Average Agricultural Wage 2006 (LM) & 0.01 & $(1.91)^{+}$ & 0.013 & $(7.74)^{* *}$ & - & - & - & - \\
\hline $\begin{array}{l}\text { Delta of average Agricultural Wage } \\
2005 \text { and } 2006 \text { (LM) }\end{array}$ & - & - & - & - & 0.01 & $(1.91)^{+}$ & 0.013 & $(7.74)^{* *}$ \\
\hline $\begin{array}{l}\text { Square of Revenue /Surplus Deficit } \\
2006-07 \text { (in Rs. Crore) }\end{array}$ & -1.33E-09 & $(-1.37)$ & 3.21E-09 & $(4.51)^{\star *}$ & $-1.33 E-09$ & $(-1.37)$ & 3.21E-09 & $(4.51)^{* *}$ \\
\hline Constant & 5.924 & 147.15 & 5.959 & 432.19 & 5.924 & $(147.15)$ & 5.959 & (432.19) \\
\hline No. of observations & \multicolumn{2}{|c|}{15} & \multicolumn{2}{|c|}{142} & \multicolumn{2}{|c|}{15} & \multicolumn{2}{|c|}{142} \\
\hline Joint Significant Test & \multicolumn{2}{|c|}{$F(4,10)=1.72$} & \multicolumn{2}{|c|}{$F(4,9)=22 \cdot 3^{* *}$} & \multicolumn{2}{|c|}{$F(4,10)=1.72$} & \multicolumn{2}{|c|}{$F(4,9)=22 \cdot 3^{* *}$} \\
\hline Adj $R^{2}$ & \multicolumn{2}{|c|}{0.1709} & \multicolumn{2}{|c|}{-} & \multicolumn{2}{|c|}{0.1709} & \multicolumn{2}{|c|}{-} \\
\hline \multirow{2}{*}{$\begin{array}{l}\text { The Breusch-Pagan / Cook-Weisberg } \\
\text { test for heteroscedasticity }\end{array}$} & \multicolumn{2}{|c|}{$C h i^{2}(4)=2.45$} & \multicolumn{2}{|c|}{-} & \multicolumn{2}{|c|}{$\mathrm{Chi}^{2}(4)=2.45$} & \multicolumn{2}{|c|}{-} \\
\hline & \multicolumn{2}{|c|}{$P$ value $=0.6535$} & \multicolumn{2}{|c|}{ - } & \multicolumn{2}{|c|}{$P$ value $=0.6535$} & \multicolumn{2}{|c|}{ - } \\
\hline
\end{tabular}

Notes: $1 .{ }^{*}=$ statistically significant at $1 \%$ level. *= significant at $5 \%$ level. $+=$ significant at $10 \%$ level.

2. Based on robust estimator based on the Huber-White heteroskedasticity-consistent covariance matrix estimator. 


\section{Concluding Observations}

The objective of this analysis was mainly to construct an intuitive measure of NREGS performance- focusing on excess demand/demand-supply gaps, changes in their distribution between 2007 and 2009, and whether excess demand became more responsive to poverty and whether hikes in NREGS wages are likely to be inflationary.

Our analysis suggests that excess demand widened slightly in the aggregate of six states during the period in question. At the state level, in Andhra Pradesh, Madhya Pradesh and Tamil Nadu, the gap narrowed substantially. By contrast, Bihar and Uttar Pradesh -especially the former- witnessed a sharp widening of excess demand.

With the same sample of districts in both years, and using a measure of standardised excess demand, the distribution in 2008-09 became more concentrated in the neighbourhoods of 0 , implying smaller deviations from the mean. However, with the comparison based on the larger sample of districts in 2008-09, the concentration is much less pronounced.

Further investigations focused on the relationship between (normalised) monthly per capita expenditure and (normalised) excess demand at the district level. Our analysis reveals a nonlinear relationship -the gaps rise over similar ranges of income to the left of 0 , fall over ranges to the right of 0 and rise again. What is also significant is that at MPCE lower than 0 the gaps were larger in 2008-09 but at higher MPCEs these were lower than corresponding gaps in 2007-08.

Our analysis of estimated excess demand further reveals that not only was it sensitive to poverty but it became more so over time in districts that were common in both 2007-08 and 2008-09. The significance of this finding lies in more poor demanding their entitlement.

If our analysis has any validity, apprehensions expressed about the inflationary potential of recent hikes in NREGS wages cannot be ruled out. Further corroboration is, however, required from a more detailed analysis. But no less important is the concern that higher NREGS wages (relative to agricultural wage rates) may undermine the self-selection of the poor in it.

In conclusion, far from losing steam, NREGS displays greater sensitiveness to demand from the poor in districts that were covered in both years in question. However, realisation of its potential for poverty reduction depends crucially on whether excess demand is reduced at a faster pace in highly poverty prone districts and whether trade-offs between poverty reduction and inflation are avoided. 


\section{References}

Ambasta, P., Shankar P.S.V., Shah, M., 2008. “Two years of NREGA: The road ahead”, Economic and Political Weekly, 43(08); 41-50.

Besley,T. and Coate, S., 1992. "Workfare versus Welfare: Incentive Arguments for Work-Requirements in Poverty Alleviation Programmes," American Economic Review, 82, pp. 249-61, March.

Chaudhuri, S. and Gupta, N., 2009. "Levels of Living and Poverty Patterns: A District-Wise Analysis for India”, Economic and Political Weekly, 28 February.

Dreze, J. and Khera, R., 2009. “The battle for employment guarantee”, Frontline, 16th January.

Gaiha, R. 1995 “Does agricultural growth matter in poverty alleviation?”, Development and Change, 26.

Gaiha, R., 2000. “Do anti-poverty programmes reach the rural poor in India?”, Oxford Development Studies, 28, pp. 71-95.

Gaiha, R., 2001. "On the targeting of the employment guarantee scheme in the Indian state of Maharashtra”. Economics of Planning, 33, 203-219.

Gaiha, R., 2007. "Employment guarantee scheme”, in The Oxford Companion to Economics in India (Ed.) K. Basu, Oxford University Press, New Delhi, pp. 129-31.

Gaiha, R. and Imai, K. 2006 “Maharashtra employment guarantee scheme”, Policy Brief 6, February 2006, London, ODI and DFID.

Gopal, K. S., 2009. “NREGA Social Audit: Myths and Reality” Economic and Political Weekly, 17th January.

Himmelfarb, G., 1984. The Idea of Poverty, New York, Knopf..

Jha, R., Bhattacharya, S., Gaiha, R., Shankar, S. 2009. “Capture” of Anti-Poverty Programs: An Analysis of the National Rural Employment Guarantee Program in India”, Journal of Asian Economics, (forthcoming).

Jha, R., Gaiha, R., Shankar, S., 2008. "Reviewing the National Rural Employment Guarantee Programme”. Economic and Political Weekly, 43(10), 44-48.

Jha, R., Gaiha, R., Shankar, S., 2009a. "National Rural Employment Guarantee Programme in Andhra Pradesh and Rajasthan: Some recent evidence”, Contemporary South Asia, (forthcoming).

Jha, R., Gaiha, and A. Sharma, 2009b. “Calorie and Micronutrient Deprivation and Poverty Nutrition Traps in Rural India”, World Development, March.

Mehrotra, S., 2008. “NREG two years on: Where do we go from here?” Economic and Political Weekly, 43(31), 27-35.

Prasad, G. and A. Antony, 2009. "High wages for rural jobs under flagship scheme may fuel inflation”, The Economic Times, 23 March.

Scandizzo, P., Gaiha, R. and Imai, K., 2009. "Option values, switches and wages: An analysis of the employment guarantee scheme in India”, Review of Development Economics, (forthcoming). 


\section{Annex}

\section{Table A.1. Definitions of variables used in the analysis}

\section{Variables Name}

\section{Dependent Variables}

Log of hh employment demand 2007-08

Log of hh employment demand 2008-09

Log of hh employment provided 2007-08

Log of hh employment provided 2008-09

Log of hh employment provided 2008-09_142

Proportion of Poor

Square of Proportion of Poor

Log of CPIAL 2006-07

\section{Explanatory and other Variables}

NREG Wage

NREG Wage Square

Lorenz Ratios

Lorenz Ratios Square

Dummy for BIMARU States

Revenue Surplus/ Deficit 2006-07

Square of Revenue Surplus/ Deficit 2006-07

Revenue Surplus/ Deficit 2007-08

Delta Revenue-Deficit (for 2006-7 and 2007-8)

Fund available in 2007-08 (Lakh)

Fund available in 2008-09 (Lakh)

Interaction of Revenue Surplus/ Deficit 2006-07 and Fund available in 2007-08

Interaction of Revenue Surplus/ Deficit 2007-08

and Fund available in 2008-09

MPCE (Rs)

MPCE Square

Normalized MPCE (Rs)

Demand Supply Gap 2007-08

Demand Supply Gap 2007-08_142

Demand Supply Gap 2008-09

Demand Supply Gap 2008-09_142

Normalized Demand Supply Gap 2007-08

Normalized Demand Supply Gap 2007-08_142

Normalized Demand Supply Gap 2008-09

Normalized Demand Supply Gap 2008-09_142

Average Agricultural Wage 2005 (LM)

Square of average Agricultural Wage 2005 (LM)

Average annual wage 2006 (LM)

Square of average annual wage 2006 (LM)

Delta of agricultural wage rate

\section{Definitions}

Log of number of households who demanded employment in 2007-08

Log of number of households who demanded employment in 2008-09

Log of number of households to whom employment is provided in 2007-08

Log of number of households to whom employment is provided in 2008-09

Log of number of households to whom employment is provided in 2007-08 (only for 142 common districts)

Proportion of poor

Square of proportion of poor

Log of CPIAL in the year 2006-07

NREG Wage (Rs.)

Square of NREG Wage

Lorenz ratios or Gini

Square of Lorenz ratios or Gini

Takes value 1 if states are Bihar, Madhya Pradesh, Rajasthan and Uttar Pradesh; 0 otherwise

Revenue surplus or deficit in year 2006-07 (in Rs. Crore)

Square of revenue surplus or deficit in year 2006-07 (in Rs. Crore)

Revenue surplus or deficit in year 2007-08 (in Rs. Crore)

Revenue surplus or deficit in year 2007-08 minus Revenue surplus or deficit in year 2006-07

Fund available in 2007-08 (Lakh Rs.)

Fund available in 2008-09 (Lakh Rs.)

Interaction of Revenue surplus or deficit in year 2006-07 and Fund available in 200708

Interaction of Revenue surplus or deficit in year 2007-08 and Fund available in 200809 (Lakh Rs.)

MPCE in Rs.

Square of MPCE in Rs.

(Actual MPCE-Mean MPCE)/Standard Deviation of MPCE

Estimated Demand Supply Gap-Mean Demand Supply Gap in 2007-08 (144 districts)

Estimated Demand Supply Gap-Mean Demand Supply Gap in 2007-08 (142 districts)

Estimated Demand Supply Gap-Mean Demand Supply Gap in 2008-09 (230 districts)

Estimated Demand Supply Gap-Mean Demand Supply Gap in 2008-09 (142 districts)

[Estimated Demand Supply Gap-Mean Demand Supply Gap]/Standard Deviation of Demand Supply Gap in 2007-08 (144 districts)

[Estimated Demand Supply Gap-Mean Demand Supply Gap]/Standard Deviation of Demand Supply Gap in 2007-08 (142 districts)

[Estimated Demand Supply Gap-Mean Demand Supply Gap]/Standard Deviation of Demand Supply Gap in 2008-09 (230 districts)

Estimated Normalised Demand Supply Gap in 2008-09 (142 districts)

Annual average wage in year 2005 only for Labour Male (Rs.)

Square of Annual average wage in year 2005 only for Labour Male

Annual average wage in year 2006 only for Labour Male (Rs.)

Square of Annual average wage in year 2006 only for Labour Male

Agricultural wage rate in 2006 minus agricultural wage rate in 2005 
Table A.1.1 Descriptive Statistics of variables used in the analysis

\begin{tabular}{|c|c|c|c|c|c|}
\hline Variables Name & Dist/States & Mean & SD & Min & $\operatorname{Max}$ \\
\hline \multicolumn{6}{|l|}{ Dependent Variables } \\
\hline Log of hh employment demand 2007-08 & 144 & 11.67 & 0.63 & 9.82 & 12.90 \\
\hline Log of hh employment demand 2008-09 & 144 & 11.66 & 0.65 & 9.32 & 12.90 \\
\hline Log of hh employment provided 2007-08 & 230 & 11.28 & 0.94 & 7.01 & 12.85 \\
\hline Log of hh employment provided 2008-09 & 230 & 11.27 & 0.93 & 7.01 & 12.85 \\
\hline Log of hh employment provided 2008-09_142 & 142 & 11.53 & 0.71 & 9.56 & 12.85 \\
\hline Proportion of Poor & 235 & 30.12 & 20.84 & 0.20 & 201.00 \\
\hline Square of Proportion of Poor & 235 & 1339.58 & 2852.59 & 0.04 & 40401.00 \\
\hline Log of CPIAL 2006-07 (Statewise) & 20 & 5.96 & 0.05 & 5.82 & 6.03 \\
\hline \multicolumn{6}{|l|}{ Explanatory and other Variables } \\
\hline NREG Wage & 237 & 79.75 & 7.93 & 67.00 & 89.67 \\
\hline NREG Wage Square & 237 & 6422.18 & 1252.21 & 4489.00 & 8040.71 \\
\hline Lorenz Ratios & 235 & -1.46 & 0.26 & -2.23 & -0.67 \\
\hline Lorenz Ratios Square & 235 & 0.06 & 0.03 & 0.01 & 0.26 \\
\hline Dummy for BIMARU States & 237 & 0.87 & 0.33 & 0 & 1 \\
\hline Revenue Surplus/ Deficit 2006-07 (Districtwise) & 237 & 1185.91 & 1620.15 & -752.00 & 3359.00 \\
\hline Revenue Surplus/ Deficit 2006-07 (Statewise) & 19 & -446.26 & 2878.80 & -8420.00 & 3359.00 \\
\hline $\begin{array}{l}\text { Square of Revenue Surplus/ Deficit 2006-07 } \\
\text { (Statewise) }\end{array}$ & 19 & 8050464.00 & 17300000.00 & 2916.00 & 70900000.00 \\
\hline Revenue Surplus/ Deficit 2007-08 & 237 & 2752.86 & 2504.25 & -101.00 & 6146.00 \\
\hline Delta Revenue-Deficit (for 2006-07 and 2007-08) & 237 & 1566.95 & 1632.80 & 18.00 & 4235.00 \\
\hline Fund available in 2007-08 (Lakh) & 144 & 7735.10 & 5167.57 & 1012.87 & 27154.90 \\
\hline Fund available in 2008-09 (Lakh) & 230 & 8794.12 & 7625.85 & 259.91 & 39241.14 \\
\hline $\begin{array}{l}\text { Interaction of Revenue Surplus/ Deficit 2006-07 and } \\
\text { Fund available in 2007-08 }\end{array}$ & 144 & 7944410.00 & 12200000.00 & -6072272.00 & 39500000.00 \\
\hline $\begin{array}{l}\text { Interaction of Revenue Surplus/ Deficit 2007-08 and } \\
\text { Fund available in 2008-09 }\end{array}$ & 230 & 17100000.00 & 21400000.00 & -1890102.00 & 97300000.00 \\
\hline MPCE (Rs) & 235 & 518.41 & 119.35 & 278.00 & 917.00 \\
\hline MPCE Square & 235 & 282934.80 & 132783.00 & 77284.00 & 840889.00 \\
\hline Normalized MPCE (Rs) & 235 & 0.00 & 1.00 & -2.01 & 3.34 \\
\hline Demand Supply Gap 2007-08 & 144 & -7971.69 & 66554.50 & -416972.10 & 117989.30 \\
\hline Demand Supply Gap 2007-08_142 & 142 & -8198.52 & 66996.73 & -416972.10 & 117989.30 \\
\hline Demand Supply Gap 2008-09 & 230 & -9945.09 & 72509.59 & -435456.20 & 88816.55 \\
\hline Demand Supply Gap 2008-09_142 & 142 & -16079.88 & 74301.41 & -435456.20 & 88816.55 \\
\hline Normalized Demand Supply Gap 2007-08 & 144 & 0.00 & 1.00 & -6.15 & 1.89 \\
\hline Normalized Demand Supply Gap 2007-08_142 & 142 & 0.00 & 1.01 & -6.15 & 1.89 \\
\hline Normalized Demand Supply Gap 2008-09 & 230 & 0.00 & 1.00 & -5.87 & 1.36 \\
\hline Normalized Demand Supply Gap 2008-09_142 & 142 & -0.08 & 1.02 & -5.87 & 1.36 \\
\hline Average Agricultural Wage 2005 (LM) & 237 & 61.84 & 11.15 & 48.40 & 81.96 \\
\hline Square of average Agricultural Wage 2005 (LM) & 237 & 3947.90 & 1465.59 & 2342.16 & 6717.72 \\
\hline Average annual wage 2006 (LM) & 237 & 64.46 & 11.86 & 48.66 & 83.16 \\
\hline Square of average annual wage 2006 (LM) & 237 & 4295.79 & 1597.91 & 2367.55 & 6915.86 \\
\hline Delta of agricultural wage rate (Statewise) & 15 & 3.28 & 2.56 & -0.74 & 7.52 \\
\hline
\end{tabular}


Table A.2

Distribution of Districts by Normalised Demand -Supply Gap

Although a chi-square test does not confirm significant changes in the relative frequencies of districts in the specified demand-supply gap intervals, there are large changes in specific intervals over the period in question. A few illustrations suffice. In the gap ranges $0-0.05$, the share of districts fell from 5.56 per cent to 3.91 districts; as also in the next higher range, $0.05-0.10$, there was a reduction (from 6.25 per cent to 4.35 per cent). At higher ranges, the relative frequencies rose from 2.78 per cent to 3.48 per cent in the range $0.10-0.15$; from 4.17 per cent to 6.09 per cent in the range $0.15-0.20$; and from 4.86 per cent to 6.96 per cent in the range $0.25-0.30$. So the changes reveal a mixed pattern.

\section{(A.2a) WITH 144 DISTRICTS IN 2007-08 AND 230 DISTRICTS IN 2008-09}

\begin{tabular}{|c|c|c|c|c|c|c|c|c|}
\hline \multirow{2}{*}{$\begin{array}{c}\text { Range of } \\
\text { Normalised } \\
\text { Gap* }\end{array}$} & \multicolumn{3}{|c|}{ 2007-08 } & \multicolumn{3}{|c|}{ 2008-09 } & \multicolumn{2}{|c|}{$\begin{array}{c}\text { Change during 2007-08 } \\
\text { and 2008-09 }\end{array}$} \\
\hline & $\begin{array}{l}\text { No. of } \\
\text { districts } \\
\text { (1) }\end{array}$ & $\begin{array}{l}\% \text { of } \\
\text { districts } \\
\text { (2) }\end{array}$ & $\begin{array}{l}\text { Cumulative \% } \\
\text { of districts } \\
\text { (3) }\end{array}$ & $\begin{array}{l}\text { No. of } \\
\text { districts } \\
\text { (4) }\end{array}$ & $\begin{array}{l}\% \text { of } \\
\text { districts } \\
\text { (5) }\end{array}$ & $\begin{array}{l}\text { Cumulative \% } \\
\text { of districts } \\
\text { (6) }\end{array}$ & $7=(5)-(2)$ & $8=(6)-(3)$ \\
\hline $0.00-0.05$ & 8 & 5.56 & 5.56 & 9 & 3.91 & 3.91 & -1.65 & -1.65 \\
\hline $0.05-0.10$ & 9 & 6.25 & 11.81 & 10 & 4.35 & 8.26 & -1.90 & -3.55 \\
\hline $0.10-0.15$ & 4 & 2.78 & 14.58 & 8 & 3.48 & 11.74 & 0.70 & -2.84 \\
\hline $0.15-0.20$ & 6 & 4.17 & 18.75 & 14 & 6.09 & 17.83 & 1.92 & -0.92 \\
\hline $0.20-0.25$ & 9 & 6.25 & 25 & 12 & 5.22 & 23.04 & -1.03 & -1.96 \\
\hline $0.25-0.30$ & 7 & 4.86 & 29.86 & 16 & 6.96 & 30 & 2.10 & 0.14 \\
\hline $0.30-0.35$ & 7 & 4.86 & 34.72 & 12 & 5.22 & 35.22 & 0.36 & 0.50 \\
\hline $0.35-0.40$ & 7 & 4.86 & 39.58 & 13 & 5.65 & 40.87 & 0.79 & 1.29 \\
\hline $0.40-0.45$ & 8 & 5.56 & 45.14 & 10 & 4.35 & 45.22 & -1.21 & 0.08 \\
\hline $0.45-0.50$ & 7 & 4.86 & 50.00 & 17 & 7.39 & 52.61 & 2.53 & 2.61 \\
\hline $0.50-0.55$ & 5 & 3.47 & 53.47 & 11 & 4.78 & 57.39 & 1.31 & 3.92 \\
\hline $0.55-0.60$ & 6 & 4.17 & 57.64 & 2 & 0.87 & 58.26 & -3.30 & 0.62 \\
\hline $0.60-0.65$ & 5 & 3.47 & 61.11 & 8 & 3.48 & 61.74 & 0.01 & 0.63 \\
\hline $0.65-0.70$ & 3 & 2.08 & 63.19 & 10 & 4.35 & 66.09 & 2.27 & 2.90 \\
\hline $0.70-0.75$ & 6 & 4.17 & 67.36 & 8 & 3.48 & 69.57 & -0.69 & 2.21 \\
\hline $0.75-0.80$ & 7 & 4.86 & 72.22 & 5 & 2.17 & 71.74 & -2.69 & -0.48 \\
\hline $0.80-0.85$ & 5 & 3.47 & 75.69 & 8 & 3.48 & 75.22 & 0.01 & -0.47 \\
\hline $0.85-0.90$ & 3 & 2.08 & 77.78 & 3 & 1.30 & 76.52 & -0.78 & -1.26 \\
\hline $0.90-0.95$ & 1 & 0.69 & 78.47 & 6 & 2.61 & 79.13 & 1.92 & 0.66 \\
\hline $0.95-1.0$ & 3 & 2.08 & 80.56 & 6 & 2.61 & 81.74 & 0.53 & 1.18 \\
\hline $1.0 \&$ above & 28 & 19.44 & 100.00 & 42 & 18.26 & 100.00 & -1.18 & 0.00 \\
\hline Aggregate & 144 & 100.00 & & 230 & 100.00 & & & \\
\hline
\end{tabular}

*We convert normalised gap (which takes both + and - values) into absolute normalised gap and then insert number of districts in each range of the gap.

Note: A chi-square test turns up a value of 14.48 (20) which is lower than the critical chi-square value 31.41 , implying that the relative frequencies in the normalised demand- supply gap intervals did not change significantly 


\section{(A.2b) WITH 142 DISTRICTS IN 2007-08 AND 142 DISTRICTS IN 2008-09}

\begin{tabular}{|c|c|c|c|c|c|c|c|c|}
\hline \multirow{2}{*}{$\begin{array}{c}\text { Range of } \\
\text { Normalised } \\
\text { Gap* }\end{array}$} & \multicolumn{3}{|c|}{ 2007-08 } & \multicolumn{3}{|c|}{$2008-09$} & \multicolumn{2}{|c|}{$\begin{array}{l}\text { Change during 2007-08 } \\
\text { and 2008-09 }\end{array}$} \\
\hline & $\begin{array}{l}\text { No. of } \\
\text { districts } \\
\text { (1) }\end{array}$ & $\begin{array}{l}\% \text { of } \\
\text { districts } \\
\text { (2) }\end{array}$ & $\begin{array}{l}\text { Cumulative \% } \\
\text { of districts } \\
\text { (3) }\end{array}$ & $\begin{array}{l}\text { No. of } \\
\text { districts } \\
\text { (4) }\end{array}$ & $\begin{array}{l}\% \text { of } \\
\text { districts } \\
\text { (5) }\end{array}$ & $\begin{array}{l}\text { Cumulative \% } \\
\text { of districts } \\
\text { (6) }\end{array}$ & $7=(5)-(2)$ & $8=(6)-(3)$ \\
\hline $0-0.05$ & 8 & 5.63 & 5.63 & 5 & 3.52 & 3.52 & -2.11 & -2.11 \\
\hline $0.05-0.10$ & 9 & 6.34 & 11.97 & 9 & 6.34 & 9.86 & 0.00 & -2.11 \\
\hline $0.10-0.15$ & 4 & 2.82 & 14.79 & 4 & 2.82 & 12.68 & 0.00 & -2.11 \\
\hline $0.15-0.20$ & 6 & 4.23 & 19.01 & 9 & 6.34 & 19.01 & 2.11 & 0.00 \\
\hline $0.20-0.25$ & 8 & 5.63 & 24.65 & 6 & 4.23 & 23.24 & -1.4 & -1.41 \\
\hline $0.25-0.30$ & 6 & 4.23 & 28.87 & 9 & 6.34 & 29.58 & 2.11 & 0.71 \\
\hline $0.30-0.35$ & 7 & 4.93 & 33.80 & 8 & 5.63 & 35.21 & 0.70 & 1.41 \\
\hline $0.35-0.40$ & 7 & 4.93 & 38.73 & 8 & 5.63 & 40.85 & 0.70 & 2.12 \\
\hline $0.40-0.45$ & 8 & 5.63 & 44.37 & 5 & 3.52 & 44.37 & -2.11 & 0.00 \\
\hline $0.45-0.50$ & 7 & 4.93 & 49.30 & 6 & 4.23 & 48.59 & -0.70 & -0.71 \\
\hline $0.50-0.55$ & 5 & 3.52 & 52.82 & 3 & 2.11 & 50.7 & -1.41 & -2.12 \\
\hline $0.55-0.60$ & 6 & 4.23 & 57.04 & 0 & 0.00 & 50.7 & -4.23 & -6.34 \\
\hline $0.60-0.65$ & 5 & 3.52 & 60.56 & 6 & 4.23 & 54.93 & 0.71 & -5.63 \\
\hline $0.65-0.70$ & 3 & 2.11 & 62.68 & 6 & 4.23 & 59.15 & 2.12 & -3.53 \\
\hline $0.70-0.75$ & 6 & 4.23 & 66.90 & 4 & 2.82 & 61.97 & -1.41 & -4.93 \\
\hline $0.75-0.80$ & 7 & 4.93 & 71.83 & 3 & 2.11 & 64.08 & -2.82 & -7.75 \\
\hline $0.80-0.85$ & 5 & 3.52 & 75.35 & 4 & 2.82 & 66.9 & -0.70 & -8.45 \\
\hline $0.85-0.90$ & 3 & 2.11 & 77.46 & 1 & 0.7 & 67.61 & -1.41 & -9.85 \\
\hline $0.90-0.95$ & 1 & 0.7 & 78.17 & 6 & 4.23 & 71.83 & 3.53 & -6.34 \\
\hline 0.95-1.0 & 3 & 2.11 & 80.28 & 5 & 3.52 & 75.35 & 1.41 & -4.93 \\
\hline 1.0 \& above & 28 & 19.72 & 100.00 & 35 & 24.65 & 100.00 & 4.93 & 0.00 \\
\hline Aggregate & 142 & 100.00 & & 142 & 100.00 & - & - & - \\
\hline
\end{tabular}

*We convert normalised gap (which takes both + and - values) into absolute normalised gap and then insert number of districts in each range of the gap.

Note: A chi-square test turns up a value of 18.63 (20) which is lower than the critical chi-square value 31.41, implying that the relative frequencies in the normalised demand- supply gap intervals did not change significantly.

If we consider the same sample of districts over the period 2007-09, a similar pattern emerges. The chi-square test suggests that the changes in the relative frequencies of districts in the specified gap intervals over the period 2007-09 are not significant. However, this does not rule out large changes in specified intervals. A few illustrations are given here. In the lowest interval, 0.0-0.05, the relative frequency of districts fell, as also in the interval, 0.40-0.45. On the other hand, in some intermediate intervals, $0.15-0.20$, and $0.25-0.30$, the relative frequencies rose. Thus the changes in relative frequencies were mixed.

The t-test results show that the mean demand-supply gaps were significant only in Bihar when the samples of 142 districts in 2007-08 were used and of 230 districts in 2008-09. The fact that the t-value is negative and significant implies that the average gap in 2008-09 was larger than that in 2007-08. This result is reproduced when the comparison of mean gaps is based on the same sample of 142 districts in both years. In Uttar Pradesh, however, the mean difference is significant and positive, implying that the gap reduced considerably in 2008-09 relative to 2007-08. 
Table: A.3

t-test Results for Comparison of Demand -Supply Gap Means Between 2007-08 and 2008-09

$\begin{array}{lcc} & \text { In } 142 \text { districts for 2007-08 \& } & \text { In } 142 \text { common districts } \\ \text { States } & \text { t-statistic } & \text { t-statistic } \\ \text { Andhra Pradesh } & -0.472 & 0.003 \\ \text { Bihar } & -7.372^{* * *} & -7.046^{* * *} \\ \text { Madhya Pradesh } & -0.369 & 1.192 \\ \text { Rajasthan } & 0.547 & 1.131 \\ \text { Tamil Nadu } & -1.185 & -0.340 \\ \text { Uttar Pradesh } & 1.099 & 3.619^{\star * *} \\ \text { All India } & 0.264 & 0.939 \\ \text { ***indicates significance at 1\% level } & & \\ \text { Note: Negative and significant t-value suggests that average gap in 2008-09 was more than that in 2007-08 while positive } \\ \text { and significant t-value shows that average gap in 2008-09 was less than that in 2007-08. }\end{array}$

Table A.4 Revenue Surplus/Deficit and Fund availability as Determinant of NREGS Supply

\begin{tabular}{|c|c|c|c|c|c|c|}
\hline & \multicolumn{6}{|c|}{$\begin{array}{c}\text { (Dep. Variable: log of hh employment provided (households which demanded } \\
\text { employment) }\end{array}$} \\
\hline & \multicolumn{2}{|c|}{ Case $A$} & \multicolumn{2}{|c|}{ Case B } & \multicolumn{2}{|c|}{ Case $\mathrm{C}$} \\
\hline & \multicolumn{2}{|c|}{ 2007-08 } & \multicolumn{4}{|c|}{ 2008-09 } \\
\hline & \multicolumn{2}{|c|}{ (144 districts) } & \multicolumn{2}{|c|}{ (230 districts) } & \multicolumn{2}{|c|}{ (142 Common Districts } \\
\hline \multirow{2}{*}{ Estimation Method } & \multicolumn{2}{|c|}{ Robust Estimation ${ }^{* 2}$} & \multicolumn{2}{|c|}{ Robust Estimation² } & \multicolumn{2}{|c|}{ Robust Estimation ${ }^{* 2}$} \\
\hline & Coef. & t value ${ }^{* 1}$ & Coef. & t value ${ }^{*_{1}}$ & Coef. & t value ${ }^{*_{1}}$ \\
\hline Revenue Deficit 2006-07 & $-5.96 \mathrm{E}-05$ & $-2.74^{\star \star}$ & - & - & - & - \\
\hline Delta Revenue-Deficit 20078-67 & $-7.80 \mathrm{E}-06$ & -0.31 & $8.52 E-05$ & $2.64^{\star *}$ & $-8.00 \mathrm{E}-06$ & -0.25 \\
\hline Fund available in 2007-08 & 7.99E-05 & $9.26^{\star \star}$ & - & - & - & - \\
\hline Revenue Deficit 2007-08 & - & - & $-1.41 \mathrm{E}-04$ & $-6.82^{\star *}$ & $-1.10 \mathrm{E}-04$ & $-5.23^{\star \star}$ \\
\hline Fund available in 2008-09 & - & - & $7.22 \mathrm{E}-05$ & $15.31^{\star *}$ & $5.38 \mathrm{E}-05$ & $8.83^{\star *}$ \\
\hline Constant & 11.150 & 98.81 & 10.972 & 145.06 & 11.349 & 106.7 \\
\hline No. of observations & & & & & & \\
\hline Joint Significant Test & $F(3,140$ & $48.37^{\star *}$ & $F(3,226$ & $143.85^{\star \star}$ & $F(3,13$ & 83.99 ** \\
\hline
\end{tabular}




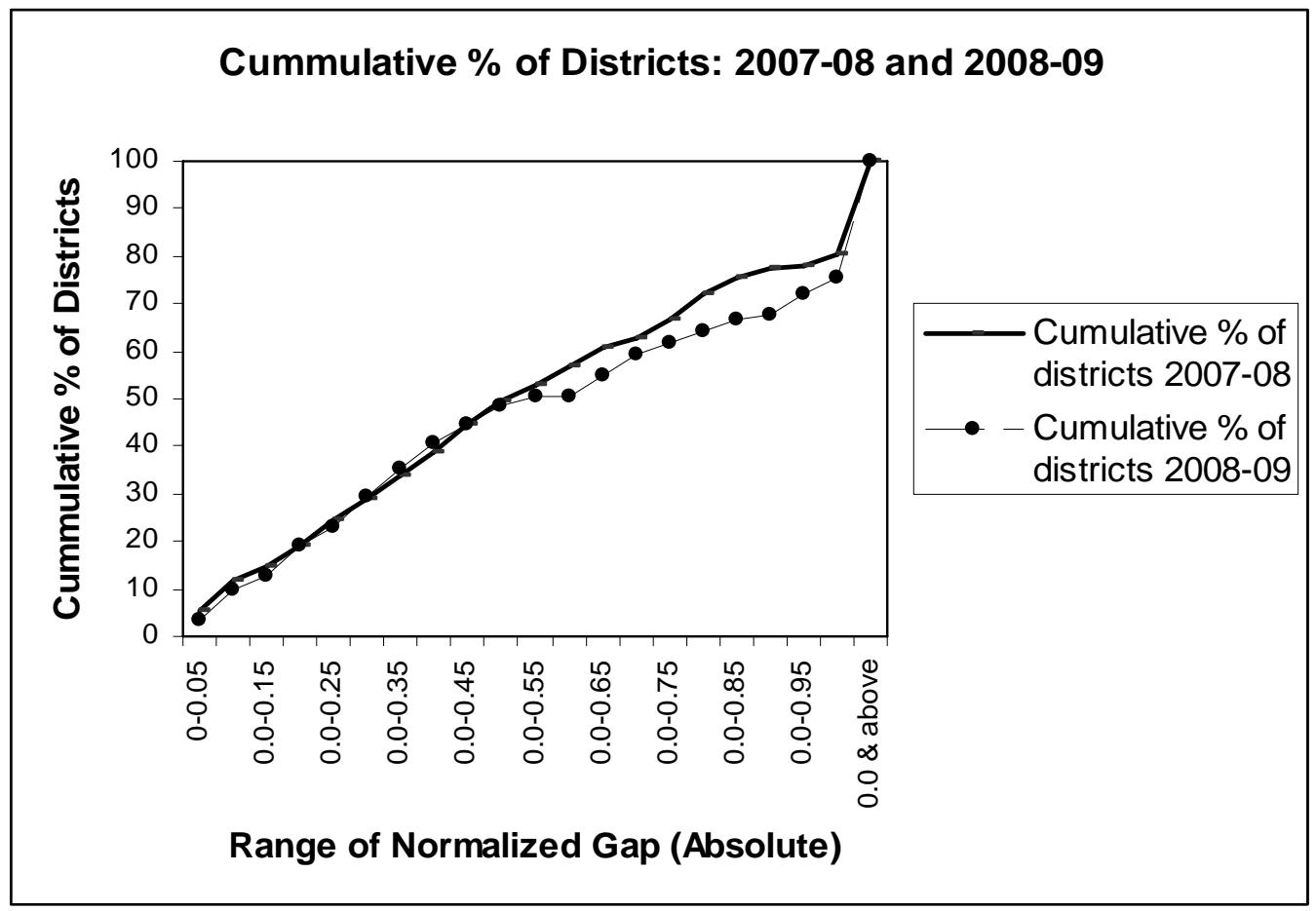

Fig: A.1.1 Cumulative Distribution of Districts by Normalised Excess Demand with 142 districts in 2007-08 and 142 districts in 2008-09

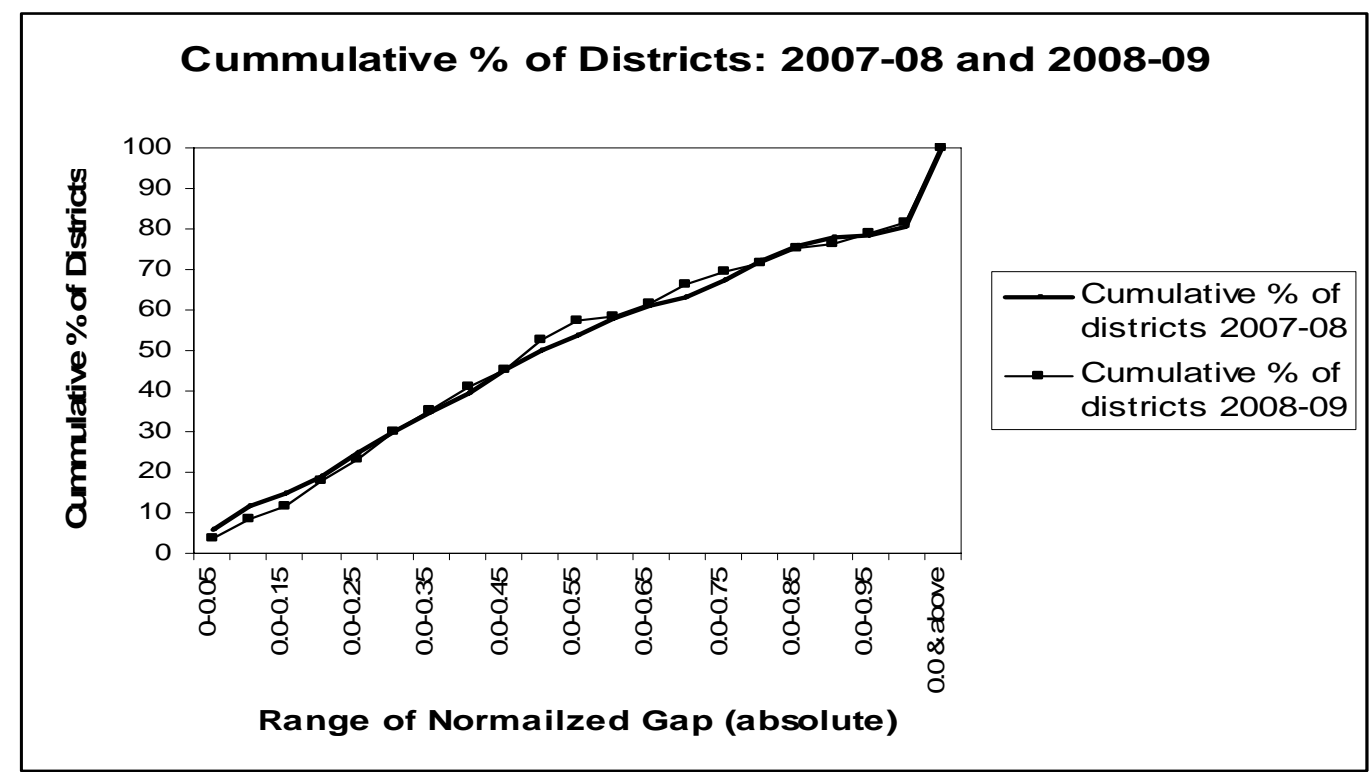

Fig: A.1.2 Cumulative Distribution of Districts by Normalised Excess Demand with 144 districts in 2007-08 and 230 districts in 2008-09 


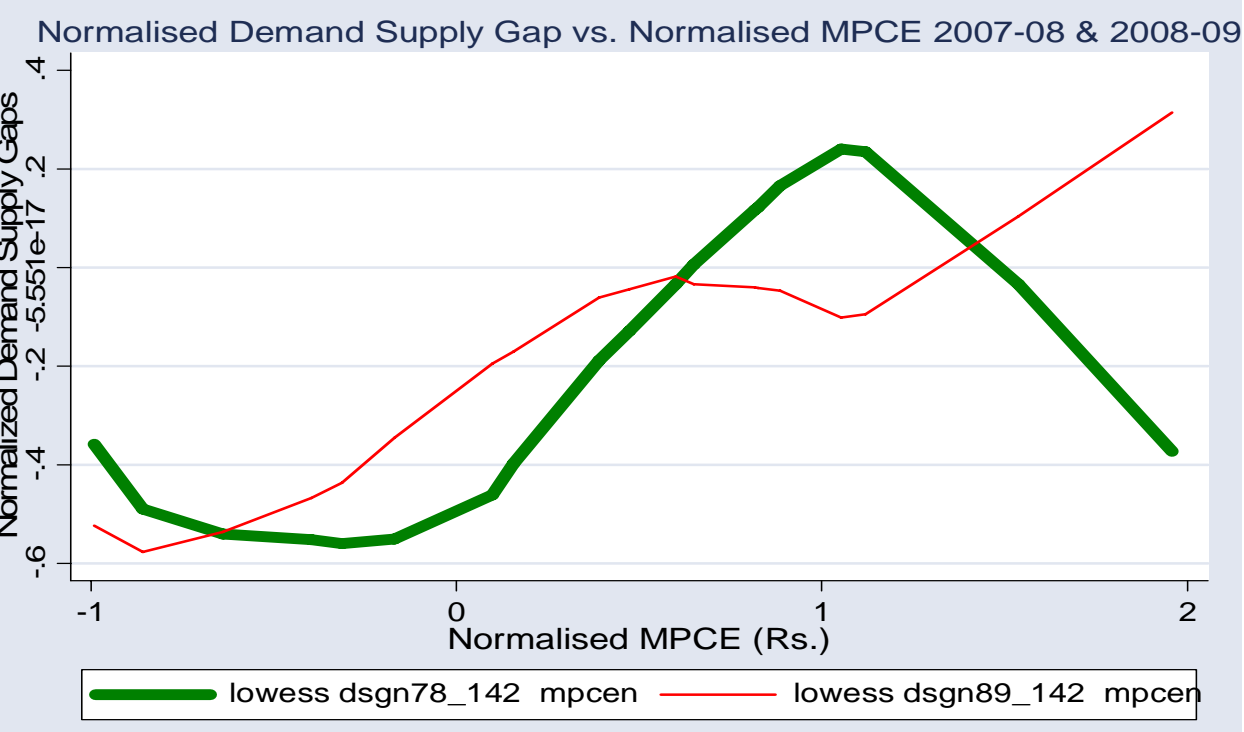

Fig: A.1.3a Normalised Excess Demand by Normalised MPCE in Andhra Pradesh for 142 districts in 2007-08 and 142 districts in 2008-09

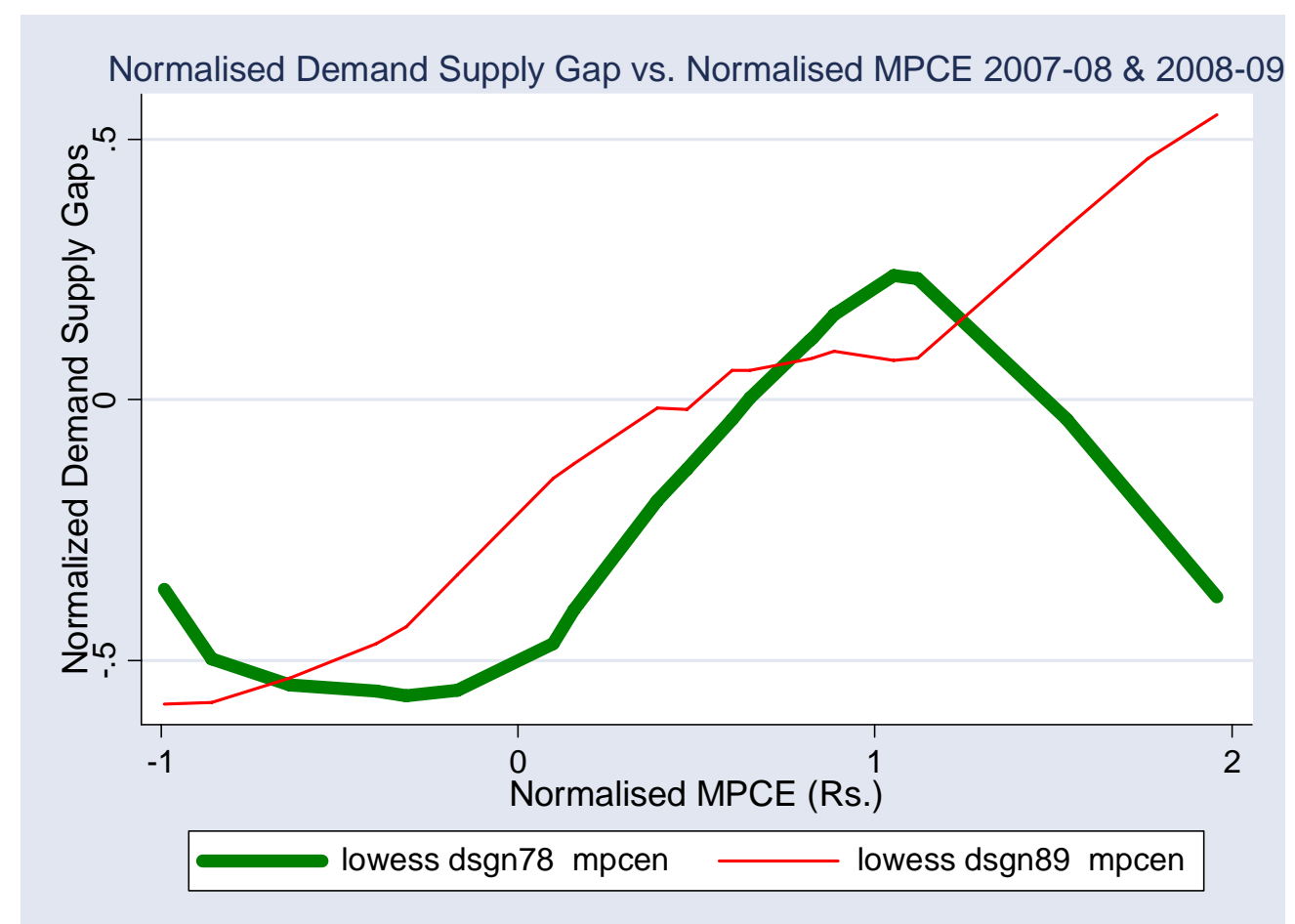

Fig: A.1.3b Normalised Excess Demand vs. Normalised MPCE in Andhra Pradesh for 144 districts in 2007-08 and 230 districts in 2008-09 


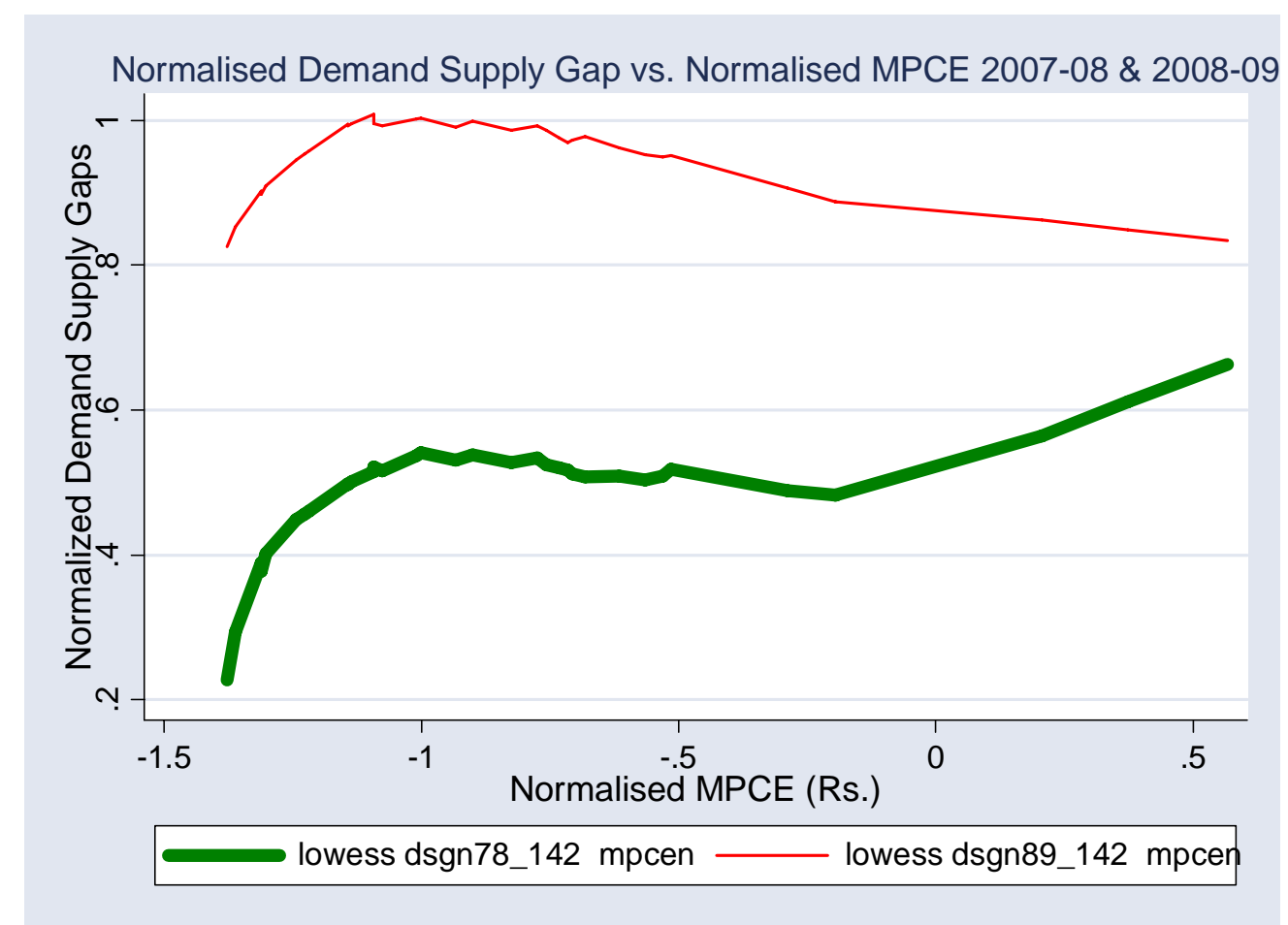

Fig: A.1.4a Normalised Excess Demand by Normalised MPCE in Bihar for 142 districts in 2007-08 and 142 districts in 2008-09

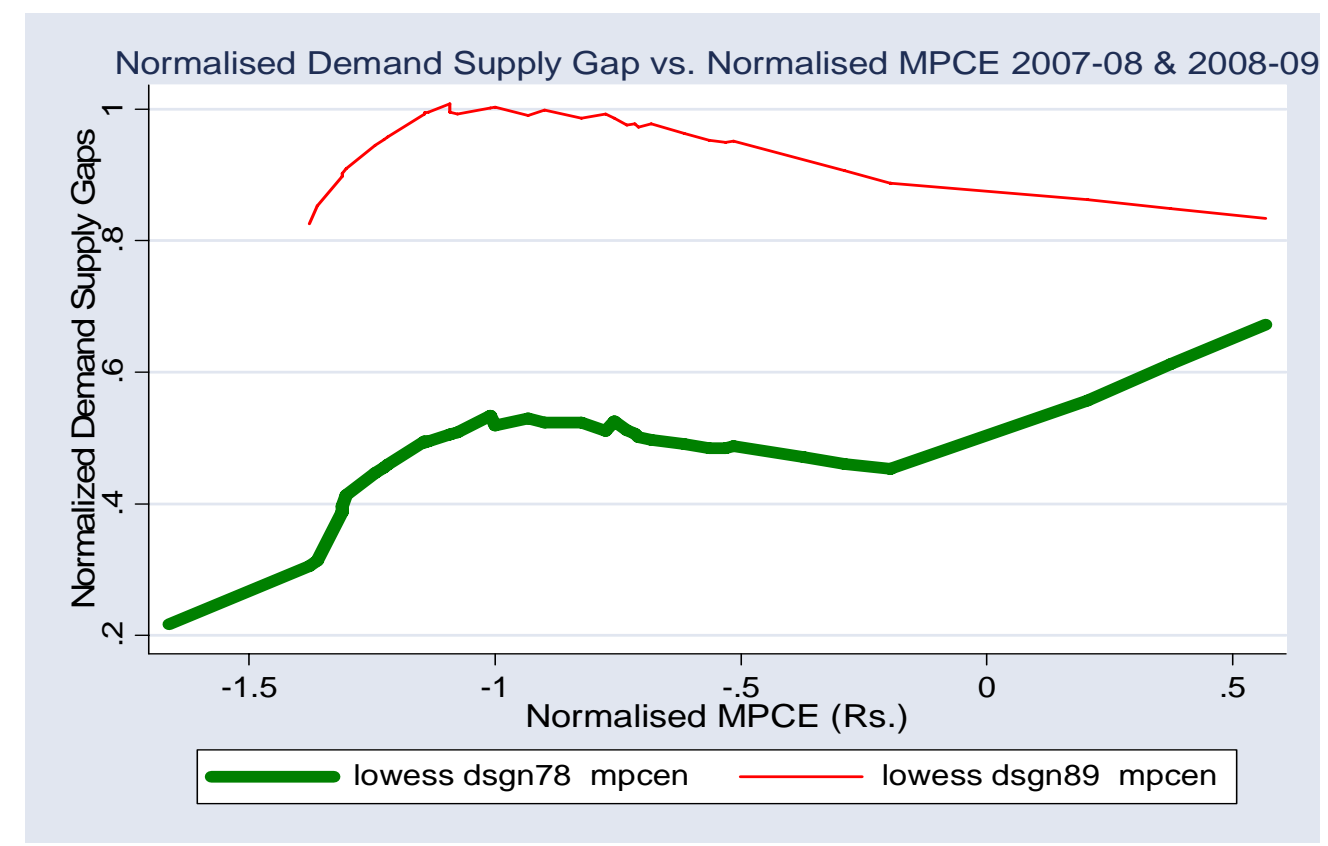

Fig: A.1.4b Normalised Excess Demand vs. Normalised MPCE in Bihar for 144 districts in 2007-08 and 230 districts in 2008-09

(A.4a) WITH 142 Districts IN 2007-08 AND 142 Districts IN 2008-09 


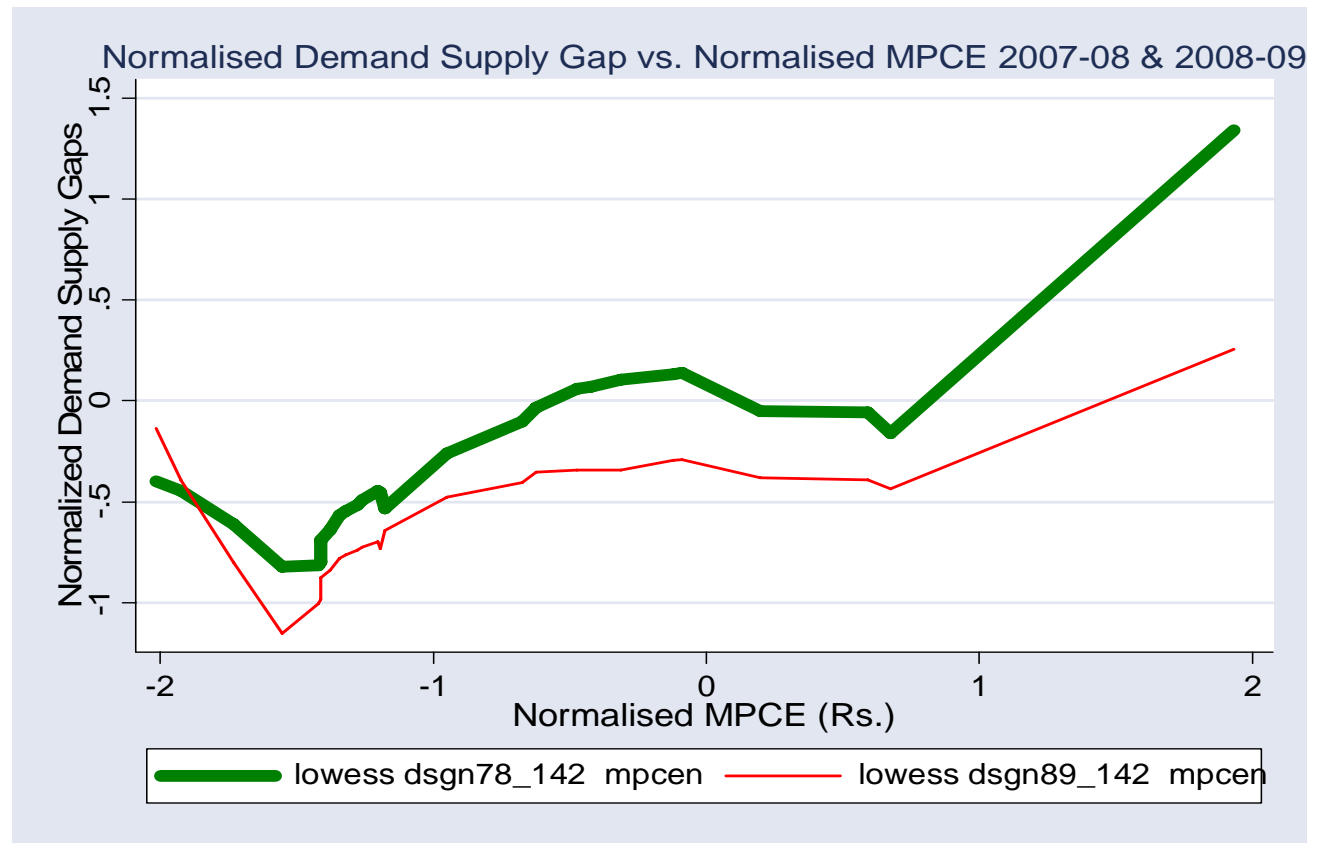

Fig: A.1.5a Normalised Excess Demand by Normalised MPCE in Madhya Pradesh for 142 districts in 2007-08 and 142 districts in 2008-09

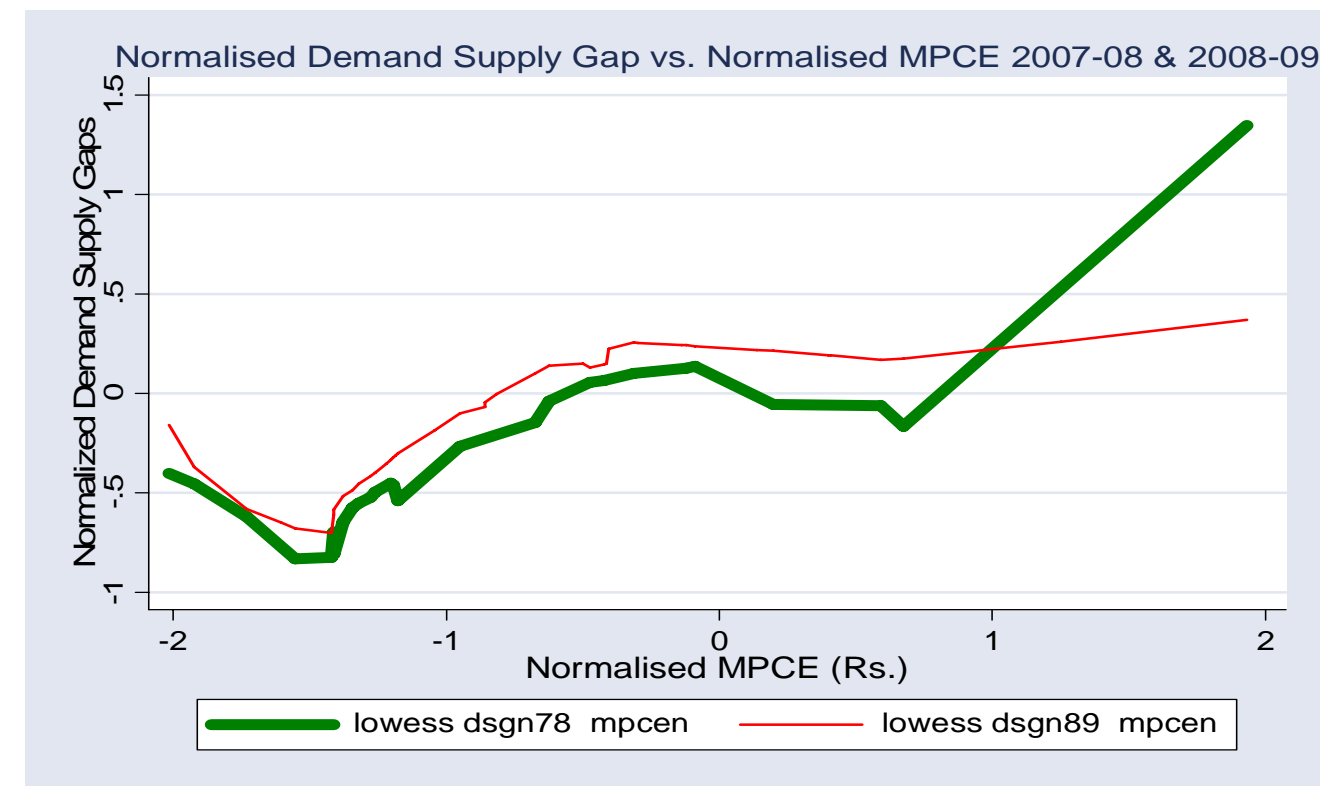

Fig: A.1.5b Normalised Excess Demand vs. Normalised MPCE in Madhya Pradesh for 144 districts in 2007-08 and 230 districts in 2008-09 


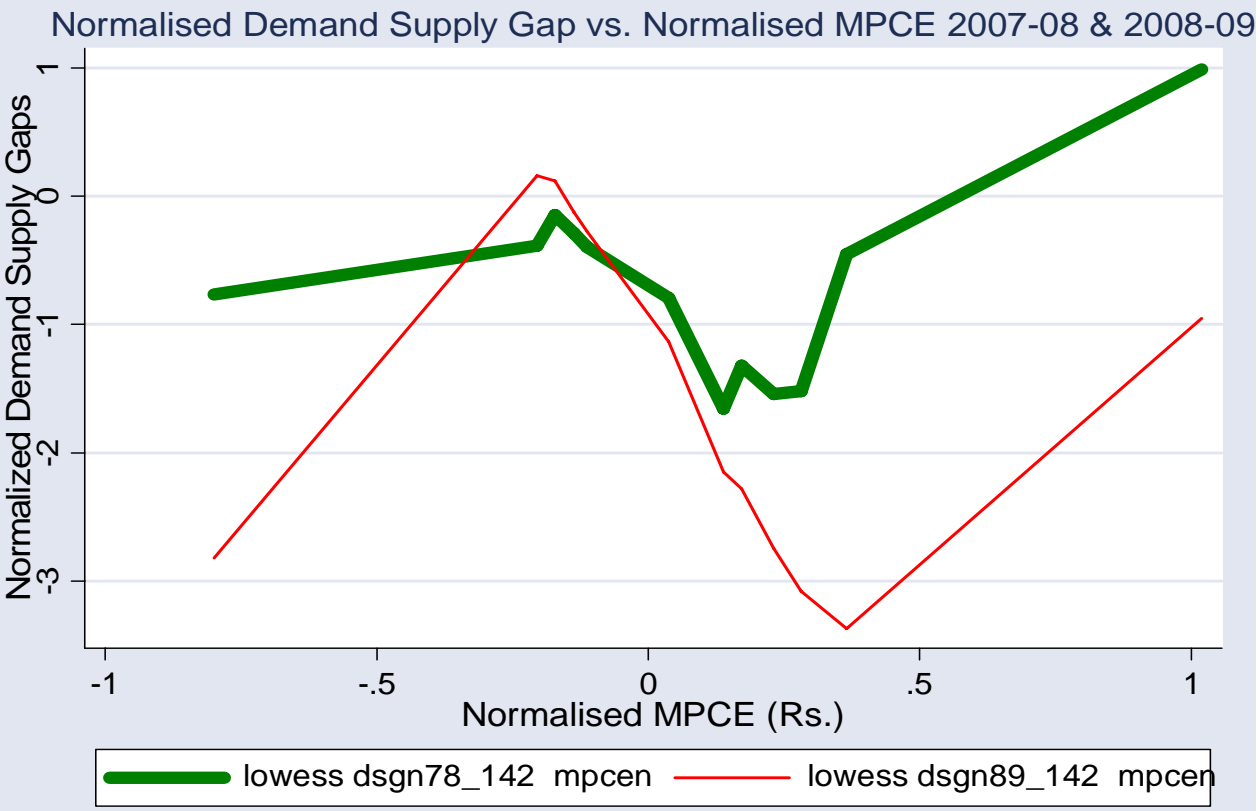

Fig: A.1.6a Normalised Excess Demand by Normalised MPCE in Rajasthan for 142 districts in 2007-08 and 142 districts in 2008-09

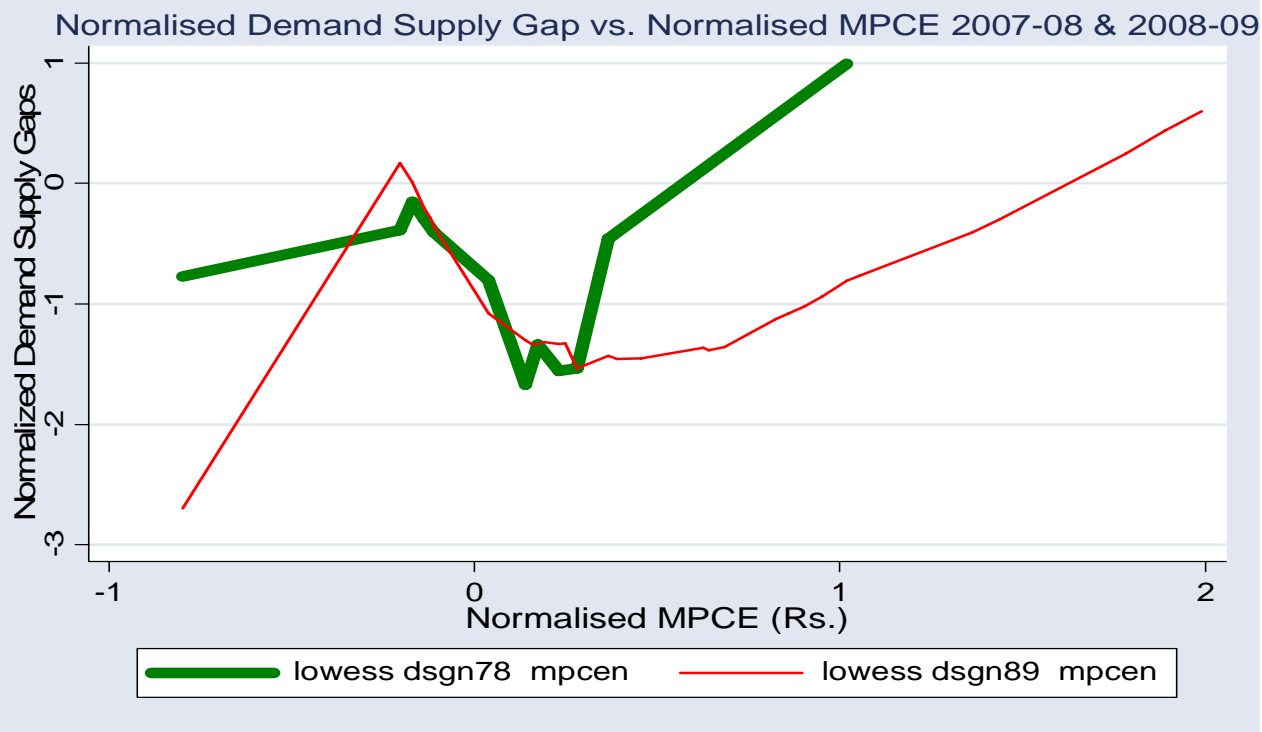

Fig: A.1.6b Normalised Excess Demand vs. Normalised MPCE in Rajasthan for 144 districts in 2007-08 and 230 districts in 2008-09 


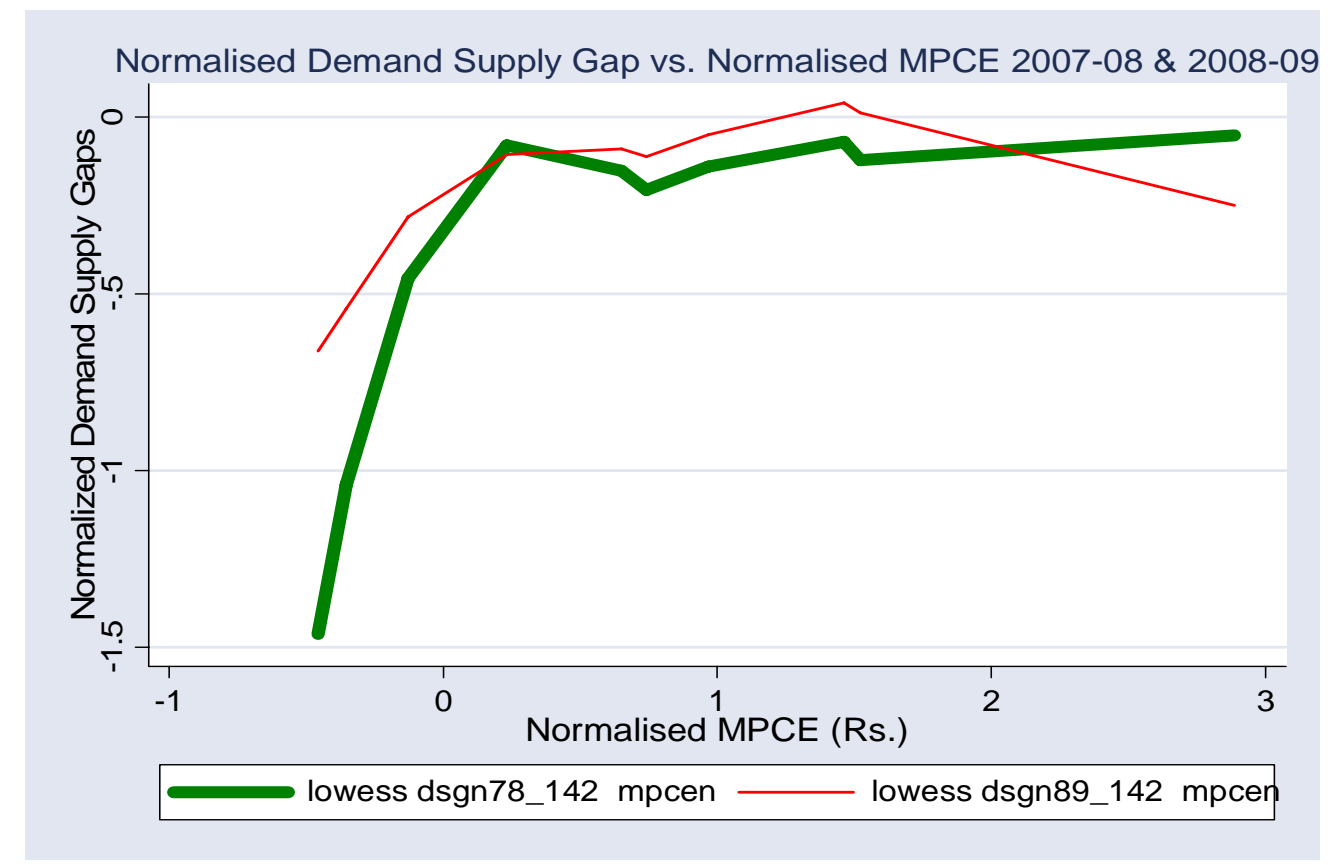

Fig: A.1.7a Normalised Excess Demand by Normalised MPCE in Tamil Nadu for 142 districts in 2007-08 and 142 districts in 2008-09

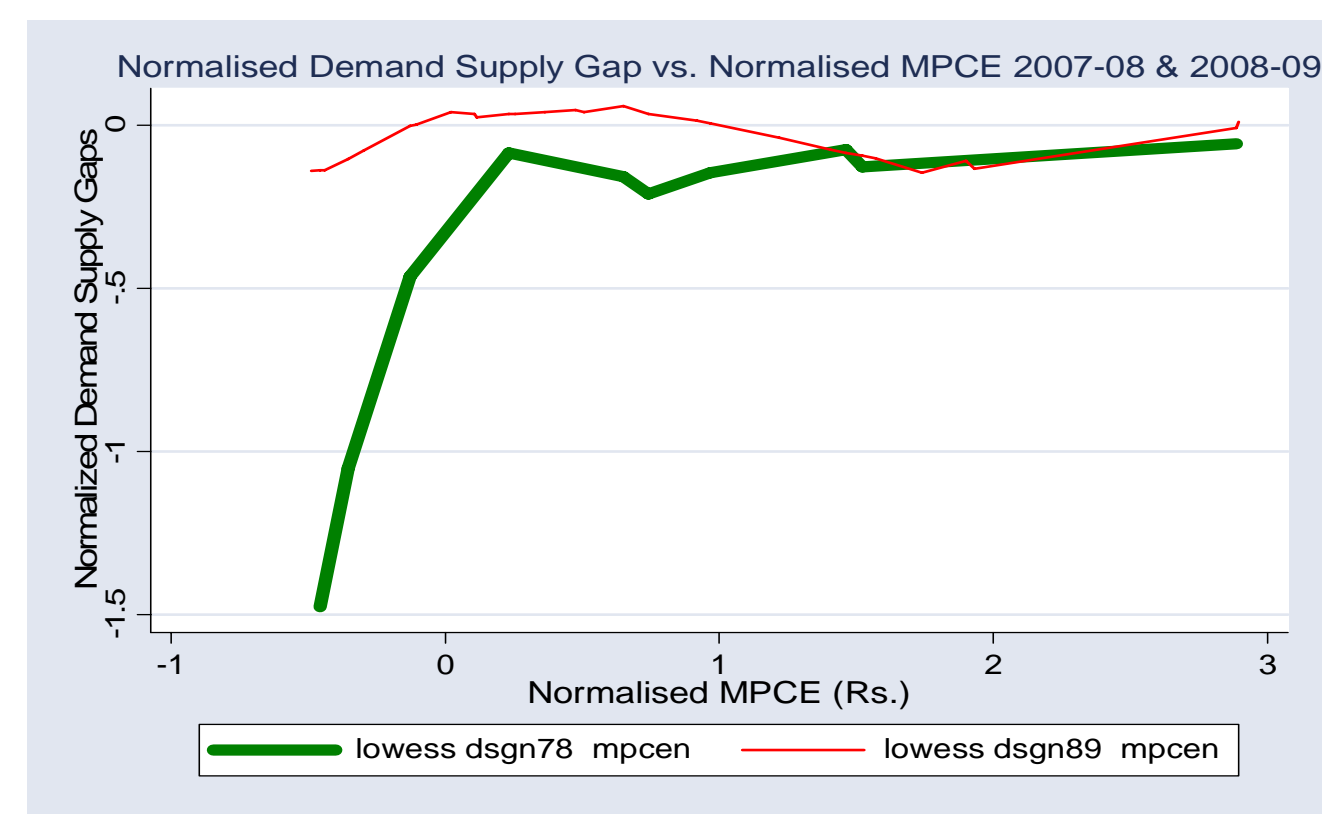

Fig: A.1.7b Normalised Excess Demand vs. Normalised MPCE in Tamil Nadu for 144 districts in 2007-๑8 and 230 districts in 2008-09 


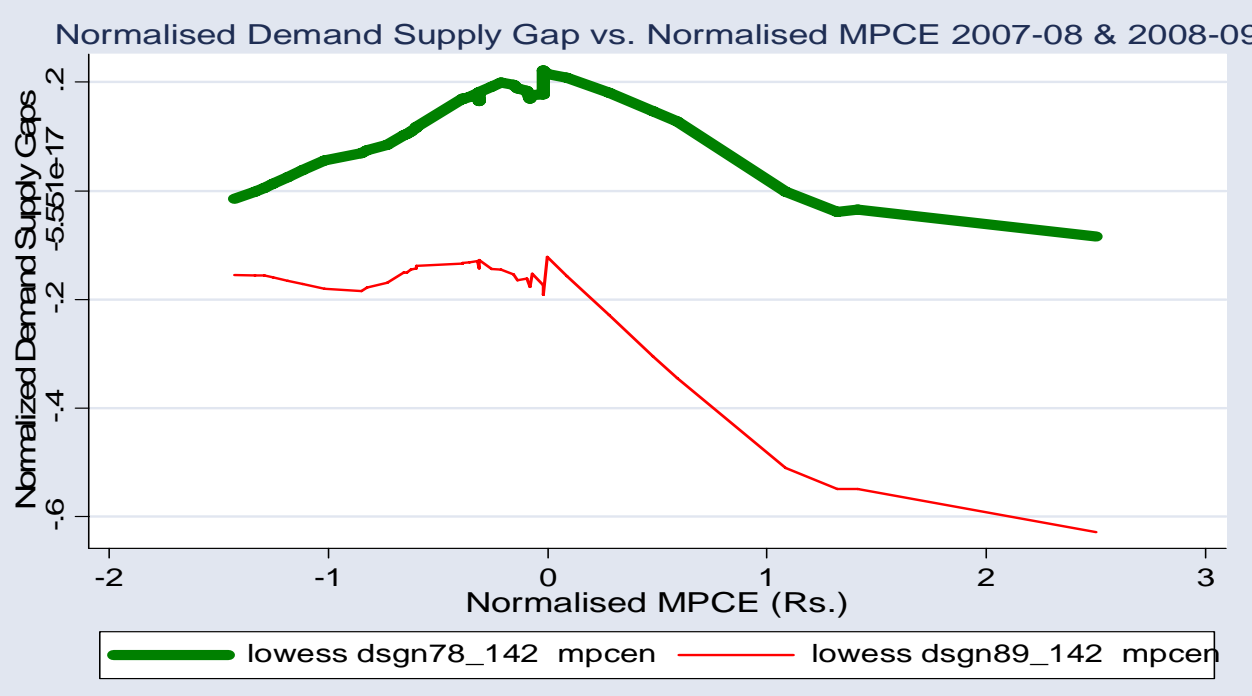

Fig: A.1.8a Normalised Excess Demand by Normalised MPCE in Uttar Pradesh for 142 districts in 2007-08 and 142 districts in 2008-09

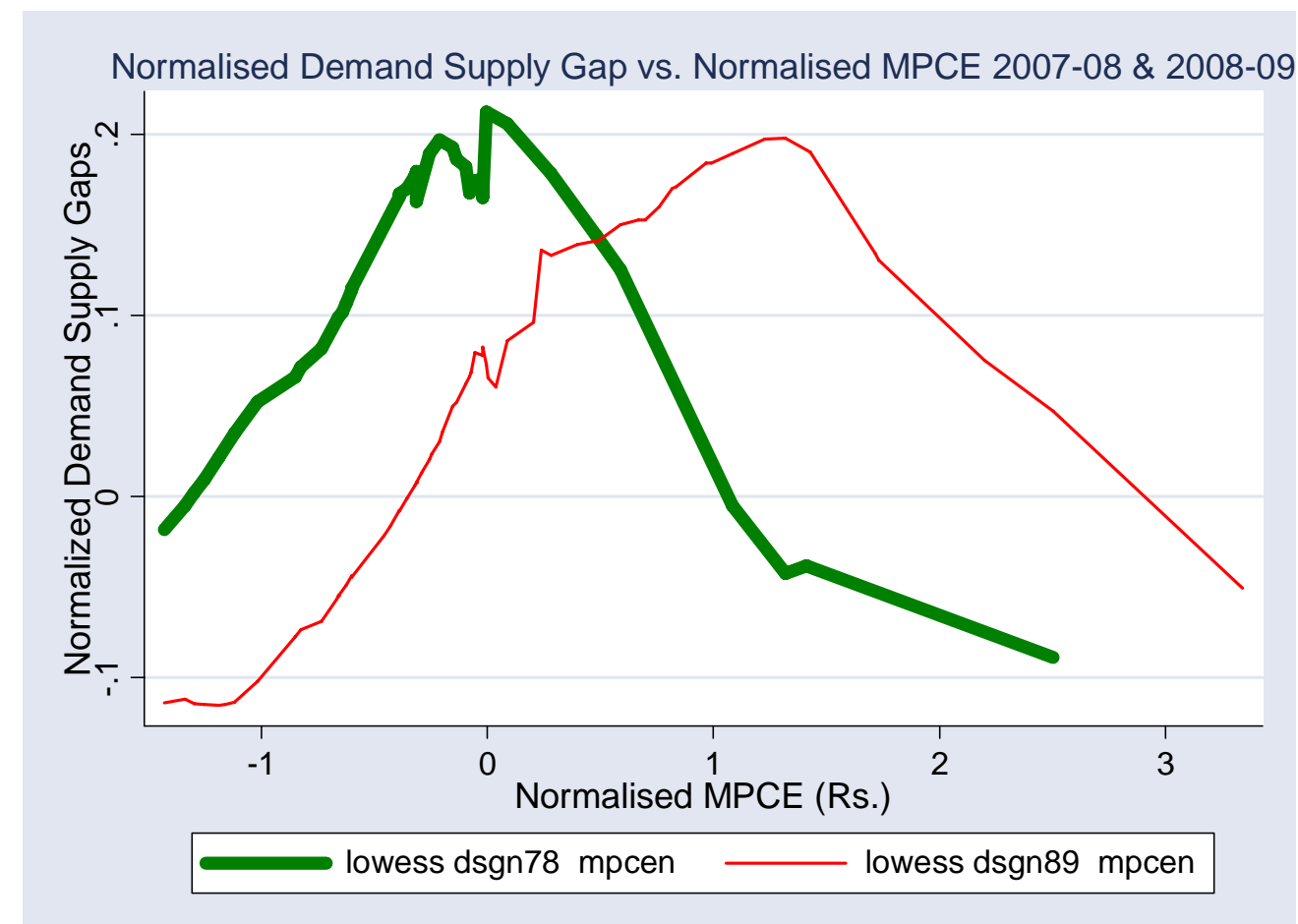

Fig: A.1.8b Normalised Excess Demand vs. Normalised MPCE in Uttar Pradesh for 144 districts in 2007-08 and 230 districts in 2008-09 